\title{
A new skull of the fossil porpoise Numataphocoena yamashitai (Cetacea: Phocoenidae) from the upper part of the Horokaoshirarika Formation (lower Pliocene), Numata Town, Hokkaido, Japan, and its phylogenetic position
}

\author{
Yoshihiro Tanaka and Hiroto Ichishima
}

\begin{abstract}
An early Pliocene porpoise, Numataphocoena yamashitai from Hokkaido, Japan, is known from the holotype, a fairly well-preserved skeleton with an incomplete skull and a referred earbone. A new skull referred to Numataphocoena yamashitai found from almost the same locality as the holotype is interesting because it expands knowledge of skull morphology and improves the diagnosis of this taxon. Numataphocoena yamashitai differs from other phocoenids in having the characteristic feature in the maxilla associated with the posterior dorsal infraorbital foramen, narrower and sharper anterior part of the internal acoustic meatus, and a robust anterior process of the periotic. A new cladistic analysis places Numataphocoena yamashitai adjacent to Haborophocoena toyoshimai and Haborophocoena minutus, among a clade of early branching phocoenids, all of which are chronologically and geographically close to each other. The new skull is probably a younger individual because it is about $80 \%$ the size of that of the holotype and it shows closed but unfused sutures. Our description of this specimen helps to understand the intraspecies variation of the extinct species Numataphocoena yamashitai.
\end{abstract}

Yoshihiro Tanaka. Numata Fossil Museum, 2-7-49, Minami 1, Numata Town, Hokkaido, 078-2225 Japan, yoshihiro.tanaka@otago.ac.nz and Hokkaido University Museum, Kita 10, Nishi 8, Kita-ku, Sapporo, Hokkaido 060-0810 Japan

Hiroto Ichishima. Fukui Prefectural Dinosaur Museum, Terao 51-11, Muroko, Katsuyama, Fukui 911-8601, Japan, hiroto.ichishima@dinosaur.pref.fukui.jp

Key words: skull; Phocoenidae; phylogeny; maxillary terrace; ontogeny; intraspecies variation

Submission: 22 March 2016 Acceptance: 20 October 2016

Tanaka, Yoshihiro and Ichishima, Hiroto. 2016. A new skull of the fossil porpoise Numataphocoena yamashitai (Cetacea: Phocoenidae) from the upper part of the Horokaoshirarika Formation (lower Pliocene), Numata Town, Hokkaido, Japan, and its phylogenetic position. Palaeontologia Electronica 19.3.49A: 1-28

palaeo-electronica.org/content/2016/1663-a-new-skull-of-numataphocoena

Copyright: @ November 2016 Society of Vertebrate Paleontology. This is an open access article distributed under the terms of the Creative Commons Attribution License, which permits unrestricted use, distribution, and reproduction in any medium, provided the original author and source are credited.

creativecommons.org/licenses/by/4.0/ 


\section{INTRODUCTION}

Since 2000, fossil phocoenid study has been progressed dramatically (Ichishima and Kimura, 2000, 2005, 2009, 2013; Fajardo-Mellor et al., 2006; Lambert, 2008; Murakami et al., 2012a, 2012b, 2015; Racicot et al., 2014; Colpaert et al., 2015). Fossil phocoenids have long been known only from the eastern and southern Pacific since the study of Salumiphocaena stocktoni (Barnes, 1985a) from the late Miocene of California by Wilson (1973), a series of Piscolithax spp reported from Peru and Mexico (de Muizon, 1983; Barnes, 1984a), and an isolated periotic described from the late Miocene of New Zealand (Fordyce, 1989). Recently, a phocoenid with a unique feeding apparatus was reported from California (Boessenecker, 2013; Racicot et al., 2014). Now, a few specimens have been known from the Atlantic (Lambert, 2008; Colpaert et al., 2015).

Tomida and Kohno (1992) described a skull from Wakkanai, Hokkaido, Japan, the first fossil record of Phocoenidae from the western North Pacific. After that, six species of fossil phocoenid have been published from Hokkaido (Ichishima and Kimura, 2000, 2005, 2009, 2013; Murakami et al., 2012a, 2012b, 2015).

Numataphocoena yamashitai from the early Pliocene of Numata Town, Hokkaido, Japan (Ichishima and Kimura, 2000) is a fairly well-preserved specimen represented by the partial skull, ear bones and postcrania. But it was too premature to perform the phylogenetic analysis for the holotype of Numataphocoena yamashitai at the time of description because of the incompleteness of the skull, which hampered a direct comparison with most other fossil phocoenids represented by the skull but lacking postcrania. A new skull, along with a referred periotic collected from the same locality (Tanaka, 2016), of Numataphocoena yamashitai allows us to determine the phylogenetic placement of the species.

Abbreviation. NFL - Numata Fossil Museum, Hokkaido, Japan.

\section{MATERIAL AND METHODS}

Numata Fossil Museum specimen NFL 2074, a skull; the premaxillae, left posterior maxilla, left frontal, left lacrimojugal, left palatine and left parietal. The specimen was originally prepared by Mr. Shigeru Yamashita using formic acid. Additional preparation was done by the first author under microscope with a fine air chisel.
NFL 2074 was collected from the riverbed of the Horonitachibetsu River, early Pliocene, upper part of the Horokaoshirarika Formation, at 4th Ebishima district, Numata Town, Hokkaido, Japan by Dr. Rei Nakashima in 1995. The site is about $3 \mathrm{~km}$ northwest of the Ishikari-Numata Station of the Japan Railroad (Figure 1).

Geological setting. In Numata Town, Hokkaido, the Miocene-Pliocene sediments, the upper and lower parts of the Horokaoshirarika Formation are about $200 \mathrm{~m}$ and $500 \mathrm{~m}$ in thickness, respectively (Watanabe and Yoshida, 1995) (Figure 1). A thin tuff, so-called Ops, separates the Horokaoshirarika Formation into the upper and lower parts (Kobayashi et al., 1969). This tuff layer is dated as $4.5 \pm 0.7 \mathrm{Ma}$, based on fission track method (Wada et al., 1986). In the lower stream of the Horonitachibetsu River, the Ichinosawa and Bibaushi Formations overlie the Horokaoshirarika Formation. The Horoshin Formation is exposed about $2 \mathrm{~km}$ upstream from this locality. NFL 2074 was collected from the upper part of the Horokaoshirarika Formation. The upper part of the Horokaoshirarika Formation yielded other marine vertebrate remains: the holotype (NFL 7) and an isolated periotic (NFL 2617) of Numataphocoena yamashitai, a tusk of Odobenini (NFL 12) and a pinniped skeleton (NFL 10) have been reported (Yamashita and Kimura, 1990; Kohno et al., 1995; Ichishima and Kimura, 2000; Tanaka, 2016). Lithology of the upper part of the Horokaoshirarika Formation is muddy to sandy sediments, with shell clusters and bioturbation (Nakashima and Majima, 2000). Paleoenvironment of the upper part of the Horokaoshirarika Formation was inner shelf (Nakashima and Majima, 2000). As it is mentioned above, Wada et al. (1986) reported the tuff age as $4.5 \pm 0.7 \mathrm{Ma}$ based on the fission track dating. Based on diatom biostratigraphy, the age of the upper part of the Horokaoshirarika Formation is 5.5 to $3.5 \mathrm{Ma}$, corresponding to the Thalassiosira oestrupii zone (Nakashima and Watanabe, 2000). The age of the upper part of the Horokaoshirarika Formation is about 4.5 to $3.5 \mathrm{Ma}$, the early Pliocene.

\section{SYSTEMATIC PALEONTOLOGY}

Order CETACEA Brisson, 1762

Unranked taxon NEOCETI Fordyce and de Muizon, 2001

Suborder ODONTOCETI Flower, 1867

Superfamily DELPHINOIDEA (Gray, 1821) Flower, 1867

Family PHOCOENIDAE Gray, 1825, sensu Burmeister, 1885 

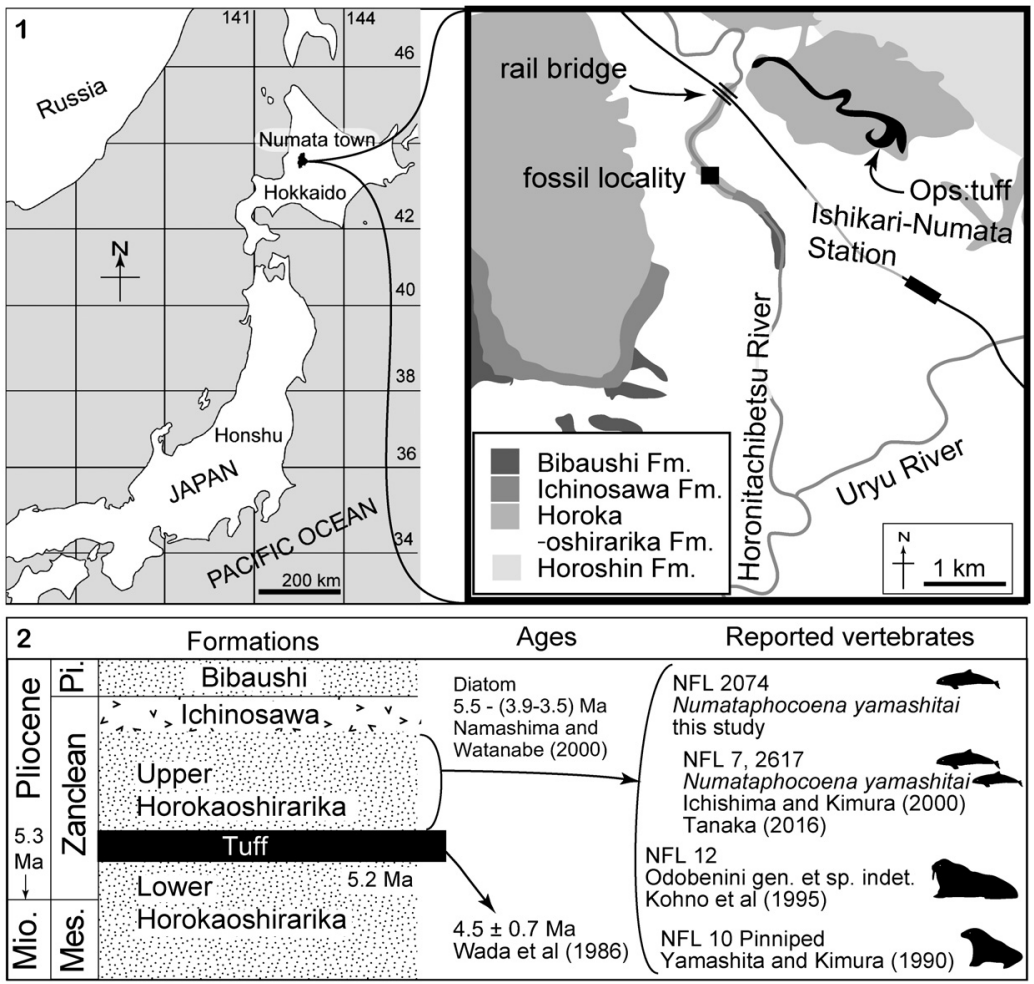

FIGURE 1. 1, Locality maps, 2, stratigraphic sections of the locality based on previous studies which are mentioned in the text. This figure is modified from Tanaka (2016).

\section{Numataphocoena yamashitai Ichishima and Kimura, 2000}

Figure 2, Figure 3, Figure 4, Figure 5, Figure 6, Table 1

Emended diagnosis. Numataphocoena yamashitai differs from other phocoenids in having a raised area along an extended sulcus from the medial border of the posterior dorsal infraorbital foramen on the dorsal surface of the maxilla, the maxillary terrace (new term, see Discussion); narrower and sharper anterior part of the internal acoustic meatus; and a robust anterior process of the periotic. Numataphocoena yamashitai differs from later branching phocoenids (such as Lomacetus, Piscolithax spp, extant species) in absence of the maxillary crest (Character 28), and wide premaxillae against the maxillae at the level of the postorbital process (Character 35).

\section{Description}

Morphological terminology for the skull follows Mead and Fordyce (2009).

Ontogenetic age. The skull sutures are mostly closed but distinct in NFL 2074. Compared with the holotype of Numataphocoena yamashitai (NFL 7), which is a physically and sexually matured individ- ual (Ichishima and Kimura, 2000), NFL 2074 is around $20 \%$ smaller in size, based on the length of the maxilla (the distance between the anterior tip of the antorbital process of the maxilla to the posterior end of the ascending process. NFL 2074: $145 \mathrm{~mm}$; NFL 7: $188 \mathrm{~mm}$ ) (Table 1). Ichishima and Kimura (2013) reported the referred specimen of Haborophocoena toyoshimai as a young individual on the basis of the incompletely fused supra/exoccipital suture, which is around $16 \%$ smaller skull size than the physically matured holotype of Haborophocoena toyoshimai. NFL 2074 is, therefore, most likely younger than the holotype.

Premaxilla. The distance between the tip of the premaxilla as preserved and the base of the rostrum at the level of the antorbital notch is $106 \mathrm{~mm}$. Each premaxilla is flat anterior to the level of the antorbital notch, and posteriorly it rises dorsally as the premaxillary eminence, which projects dorsolaterally with a weak depression on the dorsal face (the premaxillary sac fossa). In dorsal view, the posterior end of the premaxillae is widest $(27.0 \mathrm{~mm}$ on the left) at the level of the nares. A rounded end of the nasal process stops at the level of the posterior margin of the bony nares. Ventrally, the anterior 


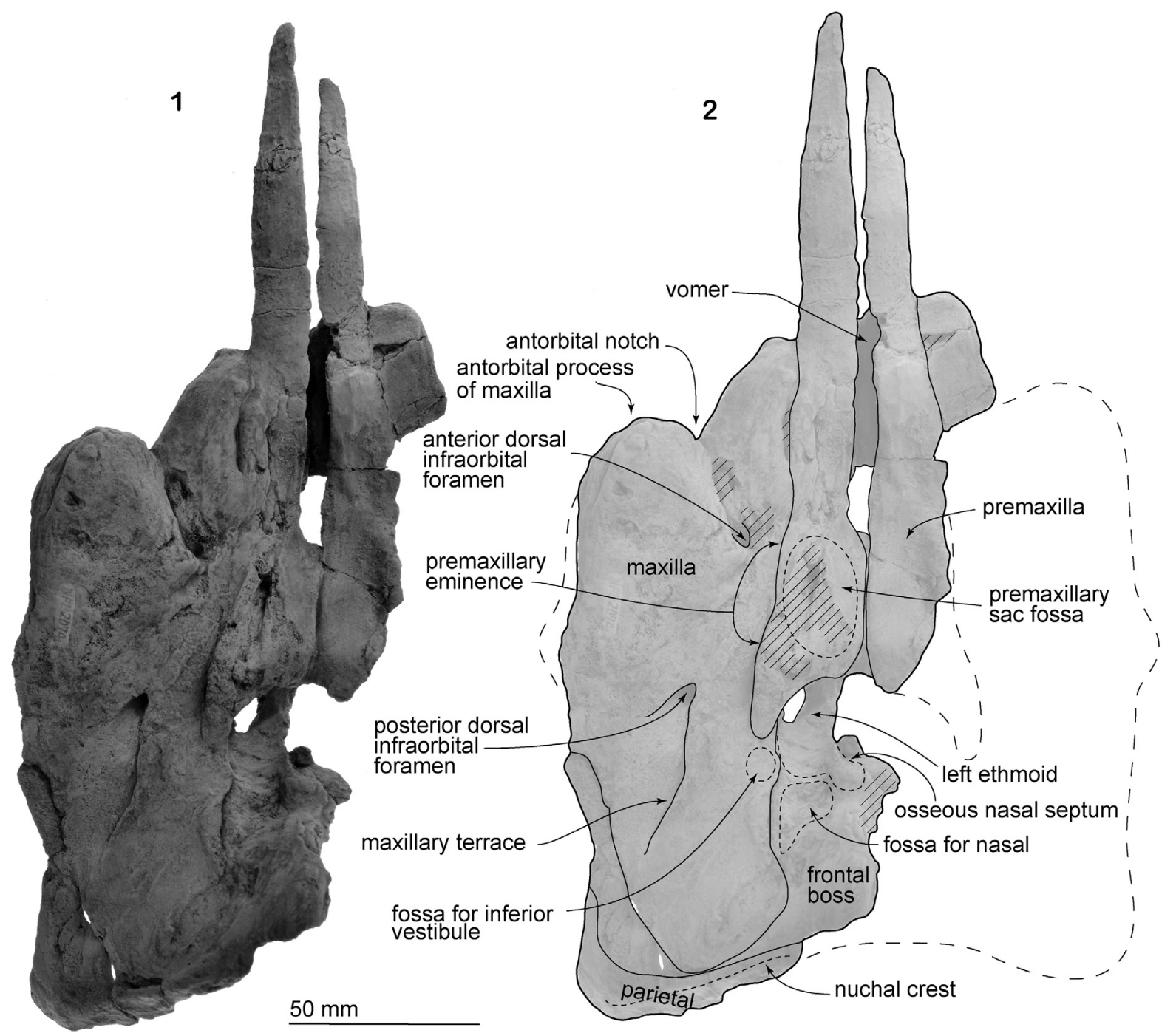

FIGURE 2. The skull, NFL 2074, referred specimen of Numataphocoena yamashitai in dorsal view. 1, photo, 2, line art.

part shows sutures with the lost maxilla laterally, and with the vomer medially.

Maxilla. The preserved cranial part of the left maxilla is dorsoventrally thin and rises gradually posterodorsally at the level of the bony nares. The base of the rostrum is wide and has a distinct antorbital notch. On the ventral face, the maxilla forms a part of the palate, which is flat anteriorly and has a weak palatal crest posteriorly. Two shallow palatine sulci run anteroposteriorly on the right maxilla. A rounded antorbital process projects anteriorly and forms a sharp and deep antorbital notch medially. Medial to the antorbital process, there is an anterior dorsal infraorbital foramen.

In dorsal view, the maxilla covers most of the frontal. The posteromedial surface of the maxilla is steep at the level of the bony nares. The posterior dorsal infraorbital foramen opens into a groove, which continues posterolaterally to an area, the maxillary terrace (new term, see Discussion), whose posterior margin reaches the lateral edge of the skull roofing over the temporal fossa. The maxillary intrusion (sensu Arnold and Heinsohn, 1996), a dorsal exposure of the maxilla medial to the premaxilla and anterior to the bony nares is uncertain. An incipient fossa for the inferior vestibule (Mead, 1975 ) is just posterior to the nasal process of the premaxilla and lateral to the bony nares. The fossa for the inferior vestibule is circular and much shallower than that of modern phocoenids, which have a small expansion medially. 

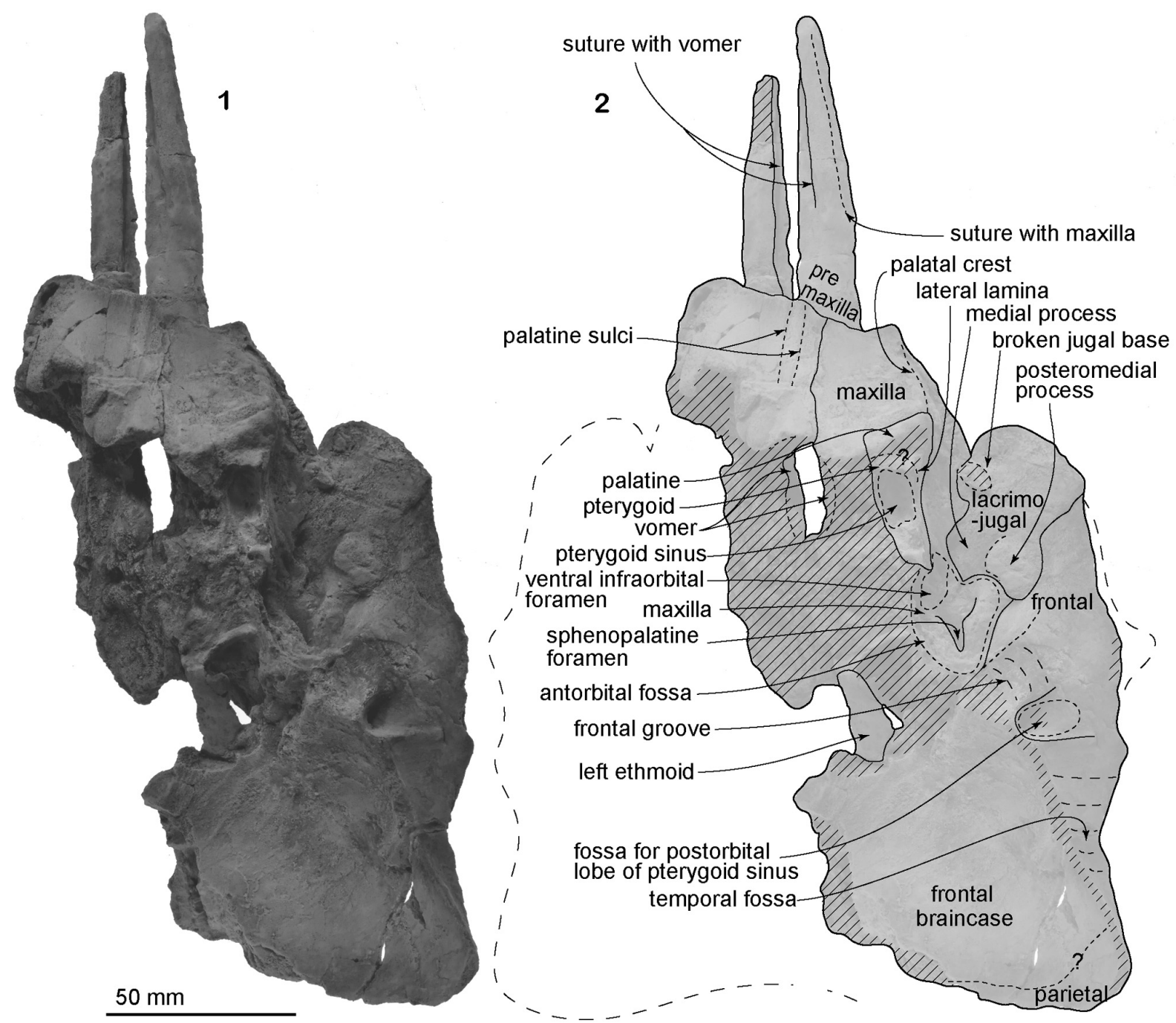

FIGURE 3. The skull, NFL 2074, referred specimen of Numataphocoena yamashitai in ventral view. 1, photo, 2, line art.

In ventral view, just posteromedial to the lacrimojugal is the antorbital fossa, which includes the ventral infraorbital foramen anteriorly and the sphenopalatine foramen posteriorly.

Palatine. Ventrally, the left palatine shows a smooth anterior wall of the pterygoid sinus fossa, which is a dorsoventrally long elliptical fossa.

Pterygoid. The left anterior fragment of the pterygoid might be on the skull, just posterior to the palatine, but the suture is not clear.

Ethmoid. The ethmoid is used in the sense of Mead and Fordyce (2009), but note that Ichishima (2011) suggested that the mesethmoid is probably absent in Odontoceti. The structure of the preserved left ethmoid is unclear in the specimen because of erosion and damage. A thin imperforated cribriform plate forms the posterior wall of the nasal passage. The cribriform plate rises to the fossa for nasals on the frontal. The dorsal end shows a partially damaged osseous nasal septum.

Vomer. An anterior broken section of the vomer can be seen in the mesorostral groove, which is $\mathrm{V}$ shaped in anterior view. The most posterior part of the vomer has been worn away.

Sphenoid. Posteromedial to the orbital rim, there is a shallow and mediolaterally long groove, which might be the frontal groove of the sphenoid. In general, the frontal groove runs from a combined large foramen of the orbital fissure and optic canal, but the medial part of the frontal groove is broken away on NFL 2074.

Frontal. The frontal contributes to the ventral surface of the orbit and the frontal boss at the vertex. The frontal boss is smooth and was originally 


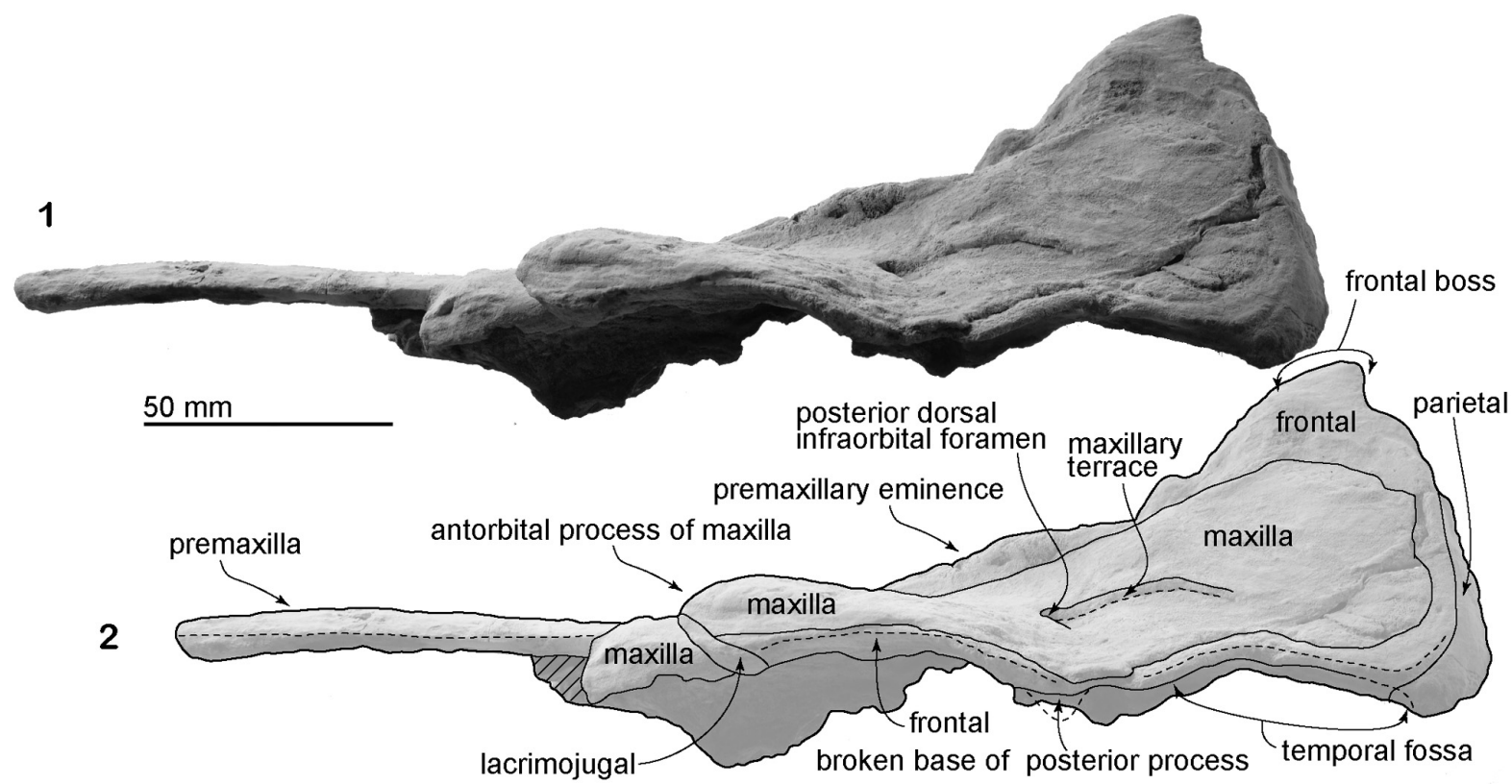

FIGURE 4. The skull, NFL 2074, referred specimen of Numataphocoena yamashitai in lateral view. 1, photo, 2, line art.

bounded by the nasals and maxillae. The frontal forms the anterodorsal wall of the braincase and ventrally exposes around a half of the shallow and long orbit. Posterior to the frontal groove, there is a shallow fossa for the postorbital lobe of the pterygoid sinus, just anterior to the temporal fossa. The nasals are not preserved, and their articular sur- faces on the frontal are shallow. The fossa for the nasal is anteroposteriorly longer than wide (around $2.0 \mathrm{~cm}$ long, $1.5 \mathrm{~cm}$ wide). The posteromedial corner of the nasal might be positioned more anterior than the posterolateral corner.

Lacrimojugal. The lacrimojugal is squared in ventral view and thin in lateral view. Its ventral surface

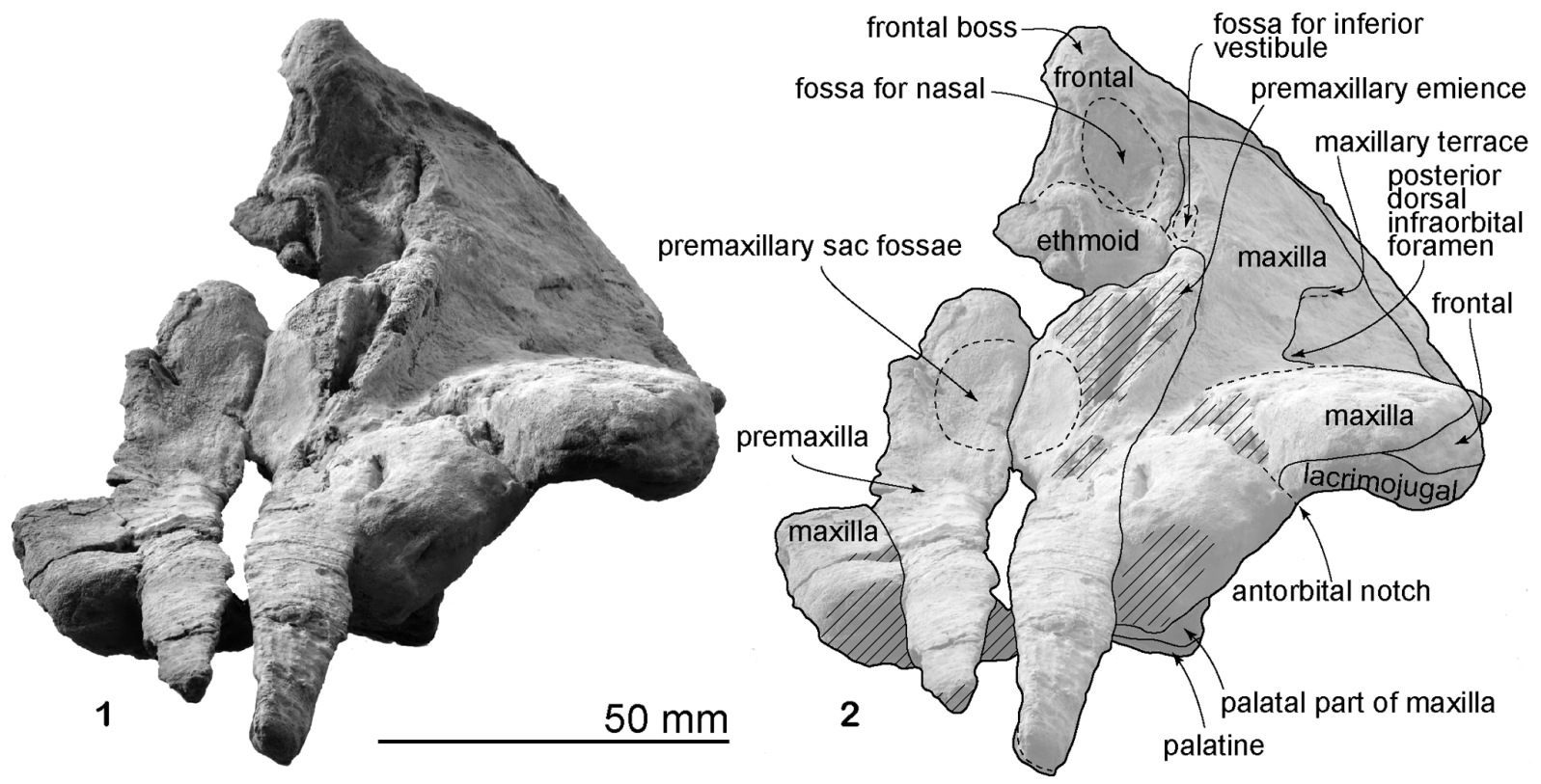

FIGURE 5. The skull, NFL 2074, referred specimen of Numataphocoena yamashitai in anterior view. 1, photo, 2, line art. 


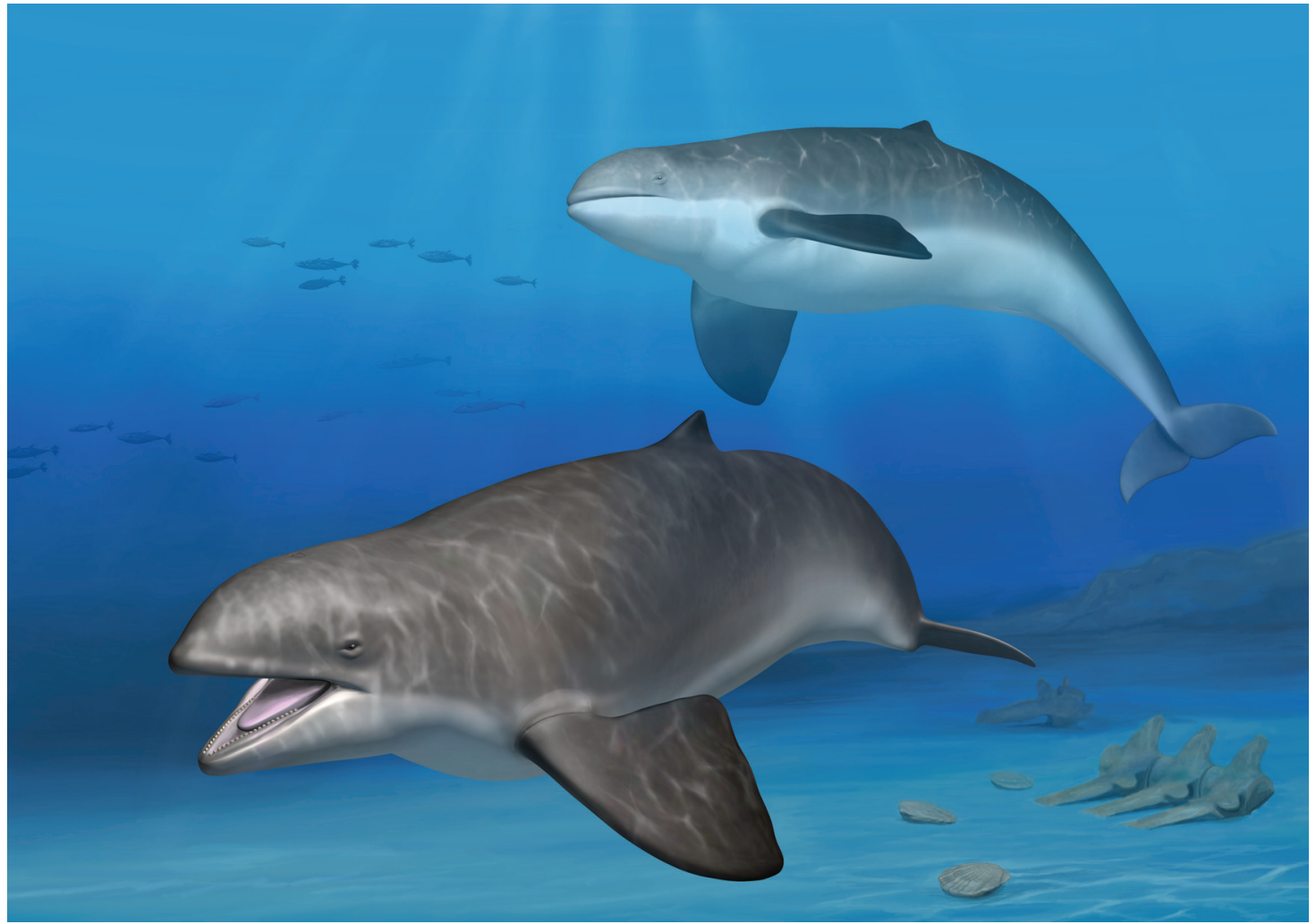

FIGURE 6. Life restoration of Numataphocoena yamashitai. Art work by Tatsuya Shinmura (Ashoro Museum of Paleontology).

is eroded. Anteromedially, there is a broken base of the lacrimojugal ( $8 \mathrm{~mm}$ diameter). The anterior border of the lacrimojugal forms the most anterior part of the antorbital process. The tubacular posteromedial process is located posterolaterally. The medial process locates medial and just a bit anterior to the posteromedial process, and is covered by the maxilla medially.
Parietal. The preserved parietal is exposed as an anteroposteriorly narrow band dorsally, just posterior to the frontal. The parietal forms the dorsal part of the temporal fossa. The parietal/frontal suture is unclear at the posterolateral part of the skull. The nuchal crest of NFL 2074 is formed by the parietal dorsolaterally and might be formed by the frontal medially. The supraoccipital is lost in NFL 2074, which might also form the nuchal crest.

TABLE 1. Measurements in mm of NFL 2074, referred specimen of Numataphocoena yamashitai: skull. Dimensions follow Fordyce et al. (2002). Measurements are rounded to the nearest $0.5 \mathrm{~mm}$. For skull and mandible, distances are either horizontal or vertical. * shows a measurement, which is only of the left side (the measurement points to the median line).

\begin{tabular}{lcc}
\hline \multicolumn{1}{c}{ Skull } & NFL 2074 & NFL 7 \\
\hline total length, from the most anterior point to posterior of occipital condyles & $260.0+$ & $199.0+$ \\
length of rostrum & $111.5^{+}$ & - \\
width of rostrum at the base & $43.5^{*}$ & - \\
cranial length & $142.5^{+}$ & $199.0+$ \\
width of premaxillae at a line across posterior limits of antorbital notches & $44.0^{*}$ & - \\
maximum width of premaxillae about the level with mid-orbit & $25.0^{*}$ & $56.0+$ \\
postorbital width, across apices of postorbital processes & $85.5^{*}$ & - \\
maximum width across narial aperture & $19.5^{*}$ & - \\
\hline
\end{tabular}




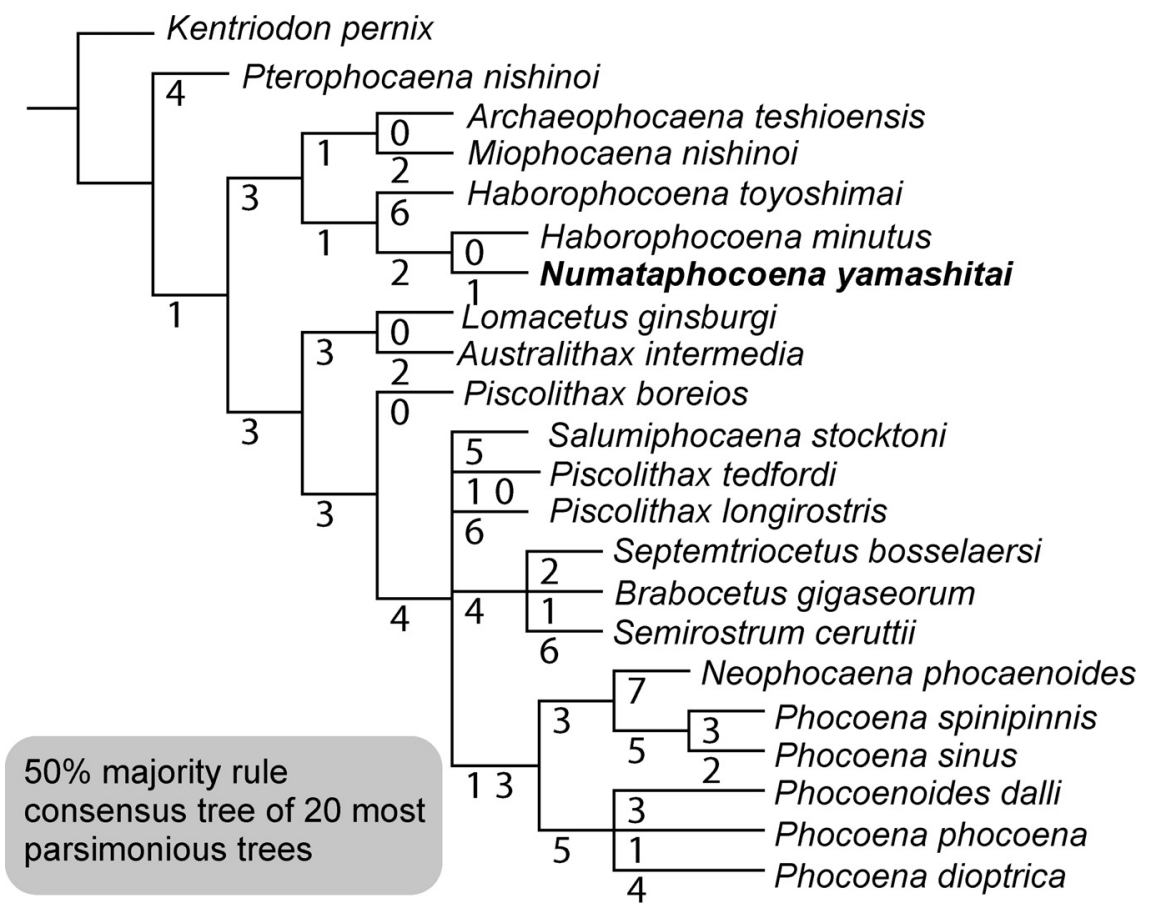

FIGURE 7. A cladogram showing relationships of the Phocoenidae. Numbers represent branch lengths.

\section{RESULTS}

\section{Phylogenetic Analysis}

The phylogenetic position of Numataphocoena yamashitai is analyzed using a new data matrix, which is modified from Tanaka and Fordyce (2015), for understanding relationships of the Phocoenidae (see Appendices 1, 2, 3, 4, 5). In the matrix, three specimens of Numataphocoena yamashitai (NFL 7, the holotype; NFL 2074, the skull of our study; and NFL 2617, a periotic) are combined. There are no contradictive codings among these specimens. Semirostrum ceruttii (Racicot et al., 2014) and Borabocetus gigaseorum (Colpaert et al., 2015) are added in the matrix. Some changes of character coding and deletions of characters from the original matrix are listed in Appendix 4.

The matrix includes 22 taxa (Kentriodon pernix as an out group) and 122 characters cited and/ or modified from previous studies (Flower, 1867, 1884; Allen, 1923; Miller, 1923; Fraser and Purves, 1960; Noble and Fraser, 1971; Kasuya, 1973; De Smet, 1977; Whitmore and Sanders, 1977; Barnes, 1984a, 1984b, 1985a, 1985b, 1990; de Muizon, 1984, 1985, 1987, 1988, 1991, 1994; Heyning, 1989, 1997; Marsh et al., 1989; Rommel, 1990; Curry, 1992; Fordyce, 1994, 2002; Arnold and Heinsohn, 1996; Luo and Marsh, 1996; Messenger and McGuire, 1998; Sanders and Barnes, 2002; Geisler and Sanders, 2003; Bianucci, 2005; Lambert, 2005, 2008; Fajardo-Mellor et al., 2006; Aguirre-Fernández et al., 2009; Mead and Fordyce, 2009; Geisler et al., 2011, 2012; Murakami et al., 2012b, 2012a, 2014; Tanaka and Fordyce, 2014, 2015). Twelve characters from Colpaert et al. (2015) and two novel characters are added to the matrix of Tanaka and Fordyce (2015).

Character data and tree data were managed using Mesquite 2.75 (Maddison and Maddison, 2011). An analysis was performed with TNT 1.1 (Goloboff et al., 2008). All characters were treated as unweighted and unordered. The analysis used New Technology Search with the setting: recover minimum length trees $=1000$ times.

The unweighted and unordered phylogenetic analysis shows 20 shortest trees of 238 steps. A tree file is provided as Appendix 5 . The $50 \%$ majority rule consensus tree (Figure 7) shows similar topology as for the result of the analysis 2 in Tanaka and Fordyce (2015) such that Pterophocaena nishinoi is placed as the earliest diverging phocoenid, all phocoenids from Hokkaido, Japan are placed as a clade, Lomacetus and Australithax are monophyletic, and extant species are monophyletic. Differences from Tanaka and Fordyce (2015) included Archaeophocaena and Miophocaena monophyly (sister taxon relationship), hav- 
ing an unresolved polytomy of Septemtoriocetus + Brabocetus + Semirostrum + Piscolithax longirostris + Piscolithax tedfordi + (Lomacetus + Australithax) + an extant clade, but having resolved extant clades.

The result of the phylogenetic analysis in our study is compared with previous studies (e.g., Fajardo-Mellor et al., 2006; Lambert, 2008; Murakami et al., 2012a, 2012b, 2014, 2015; Racicot et al., 2014; Colpaert et al., 2015). The topology is similar in pattern with those of Murakami et al. (2012a, 2012b, 2014, 2015), in which Pterophocaena nishinoi is reconstructed as the earliest diverging phocoenid; all phocoenids from Hokkaido are placed as a clade; Lomacetus and Australithax as a clade; and extant species as monophyletic. Colpaert et al. (2015) reconstructed Pterophocaena nishinoi basal to all phocoenids as similar to this study, but among an unresolved polytomy with Delphinodon dividum and Kentriodon pernix. Both in our study and the Murakami studies, just crownward from Pterophocaena nishinoi, a clade of Archaeophocaena teshioensis and Miophocaena nishinoi are recovered. Colpaert et al. (2015) placed A. teshioensis and Miophocaena nishinoi with Semirostrum ceruttii as an unresolved polytomy. This study shows an unresolved polytomy, which includes Salumiphocaena $+P$. tedfordi $+P$. longirostris + (Septemtriocetus + Brabocetus + Semirostrum) + an extant clade. Salumiphocaena stocktoni was reported from the early late Miocene (12.6 to $9.0 \mathrm{Ma}$ ) Valmonte Diatomite Member in California (Wilson, 1973; Barnes, 1985a), which is possibly the oldest known record of the Phocoenidae (Uhen et al., 2008). Semirostrum ceruttii is placed as one of the most crownward extinct species in our study and also Racicot et al. (2014). Just basal from the extant clade, our study has a clade of Septemtriocetus + Brabocetus + Semirostrum. In Colpaert et al. (2015), Brabocetus was placed just basal to the Septemtriocetus. The three species of Piscolithax do not form a clade in this study and the previous studies, except Fajardo-Mellor et al. (2006).

\section{DISCUSSION}

\section{Comparison Between the Skulls of Numataphocoena yamashitai Holotype and NFL 2074}

Numataphocoena yamashitai can be diagnosed by having the maxillary terrace (new term). The maxillary terrace is a raised area along a sulcus from the medial border of the posterior dorsal infraorbital foramen. Modern phocoenids also have the raised area and sulci from the posterior dorsal infraorbital foramen, but they are much shorter sulcus and weaker raised area than in Numataphocoena yamashitai.

The maxillary terrace is a natural structure, not a taphonomic artifact because the internal wall of the braincase does not show any deformations (holotype; NFL 7 and referred specimen; NFL 2074).

Comparison of the maxillary terrace in the holotype NFL 7 and the referred skull NFL 2074 reveals that the relationships of the maxillary terrace and the dorsal infraorbital foramen are different (Figure 8). On NFL 2074, the maxillary terrace is restricted by a sulcus extending from the medial border of the posterior dorsal infraorbital foramen, and its length is about $46 \mathrm{~mm}$. On the other hand, the holotype NFL 7 shows an extra-extended sulcus, which continues anterior to the posterior dorsal infraorbital foramen. The anterior part of the maxillary terrace is broken in NFL 7, and the length of the sulcus is $55+\mathrm{mm}$. The anterior part of the sulcus is seen only on the holotype. Additional skulls are required to consider the maxillary terrace variation.

In addition to the maxillary terrace, some morphological differences exist between NFL 7 and NFL 2074. The nuchal crest is different in the degree of development. In NFL 7 the nuchal crest is well-developed and rises dorsally, and its anterior margin is weakly bowed down anteriorly, continuing to the lateral margin of the frontal boss. On the other hand, NFL 2074 has an incipient crest on the preserved lateral part of the frontal. These differences may be due to ontogenetic variation as NFL 2074 is discussed as younger individual based on the skull size and fusions of the skull sutures. However, in an ontogenetic study of Stenella coeruleoalba, Ito and Miyazaki (1990) reported sexual dimorphism of the skull. Females over three years of age have a developed nuchal crest, compared to males, in which the nuchal crest is not developed at any growth stage. Thus, if Numataphocoena yamashitai had sexual variation on the nuchal crest like Stenella coeruleoalba, and if NFL 2074 was a different sex to NFL 7, NFL 2074 might not have developed a conspicuous nuchal crest even at attainment of physical maturity.

\section{A Clade of Fossil Phocoenids from Hokkaido}

The phylogenetic results show a clade of fossil phocoenids, which includes Archaeophocaena, 


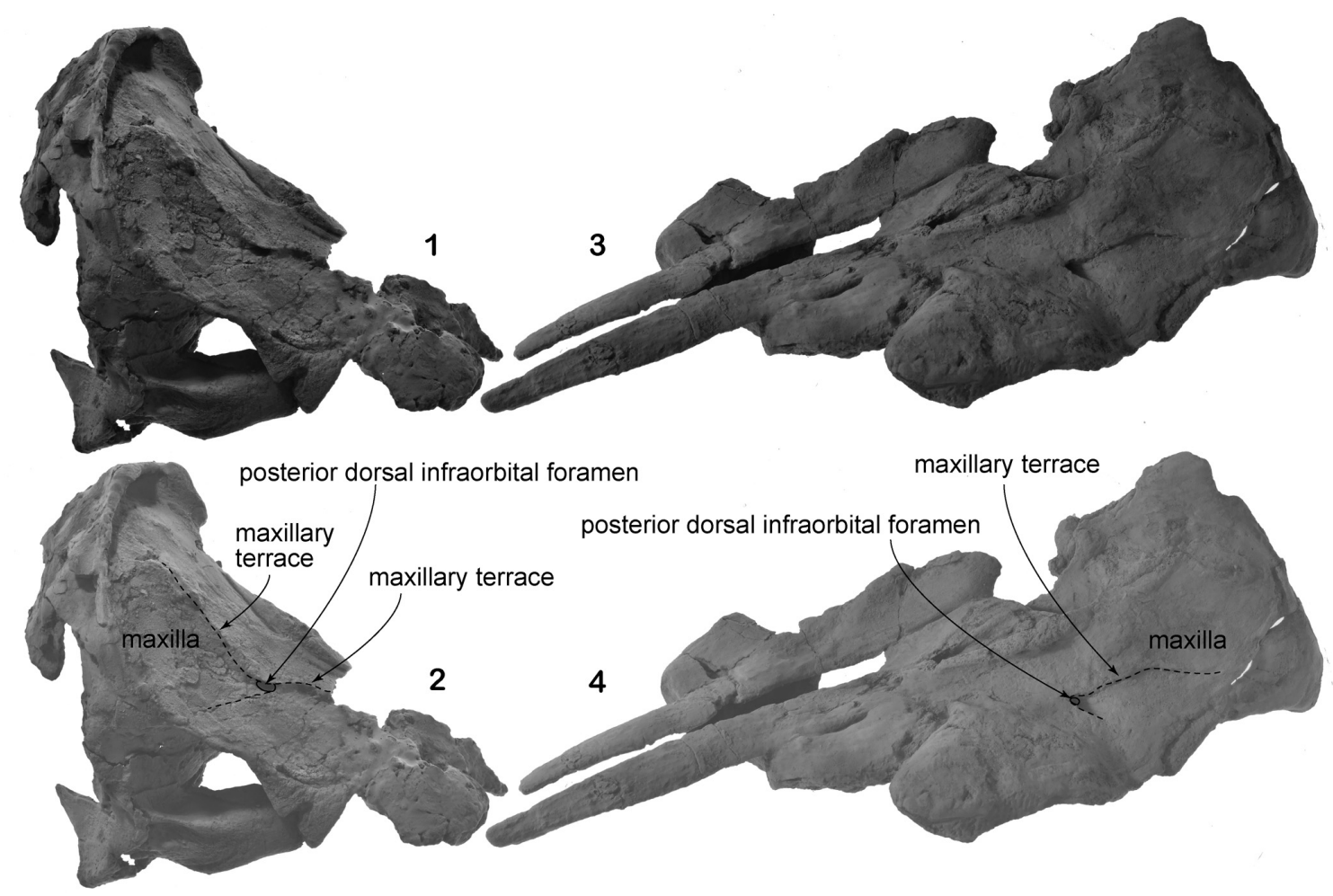

FIGURE 8. The maxillary terrace from the posterior dorsal infraorbital foramen on the maxilla. 1 and 2 , NFL 7 , the type of Numataphocoena yamashitai. 3 and 4, NFL 2074, the referred specimen.

Miophocaena, and Haborophocoena spp. and Numataphocoena from the late Miocene to early Pliocene of Hokkaido, Japan. As an exception, Pterophocaena nishinoi, one of the phocoenids from Hokkaido is not included in the clade of fossil phocoenids from Hokkaido, and is reconstructed as just crown to the outgroup Kentriodon in our analysis. The clade of Hokkaido phocoenids has never been discussed before although the clade appeared in the appendix in an implied analysis (down weighting homoplastic characters) of Tanaka and Fordyce (2015), which is the original matrix of this study. A similar clade is seen in the results of Colpaert et al. (2015), which included four Hokkaido phocoenids (Haborophocoena spp., Miophocaena and Archaeophocaena).

The clade of Hokkaido phocoenids in this study is supported by three synapomorphies; the premaxillary foramen medial to the center of the premaxilla (Character 22), wide premaxillae compared to the rostrum at antorbital notch (Character 34 ), and the anterior-most dorsal infraorbital foramen lies posterior to the level of the antorbital notch (Character 114). A fossil phocoenid from Hokkaido, Pterophocaena nishinoi has the premaxillary foramen at the midpoint of the premaxilla
(Character 22), and the anterior-most dorsal infraorbital foramen is located anterior to the antorbital notch (Character 114). Having a low premaxillary eminence is one of the diagnostic features of the clade of Hokkaido phocoenids. Pterophocaena does not have the premaxillary eminence. The low premaxillary eminence is also seen in the Atlantic species, Brabocetus and Septemtriocetus.

Our analysis recognizes two subclades, rather than having a pectinate topology of the stem taxa in which the clade of Hokkaido phocoenids (Numataphocoena and Haborophocoena) and another clade (Lomacetus, Piscolothax, Semirostrum and other species + extant species). The clade of Hokkaido phocoenids is branching immediately with a clade of the extant + Eastern Pacific + Atlantic clades. It means that the Phocoenidae was separated into Eastern and Western Pacific clades in the Late Miocene to Early Pliocene, early in the history of phocoenids (Figure 9).

Phocoenids from Hokkaido phocoenids includes two subclades, the Archaeophocaena + Miophocaena clade and the Haborophocoena toyoshimai + (Numataphocoena yamashitai + Haborophocoena minutus) clade. 


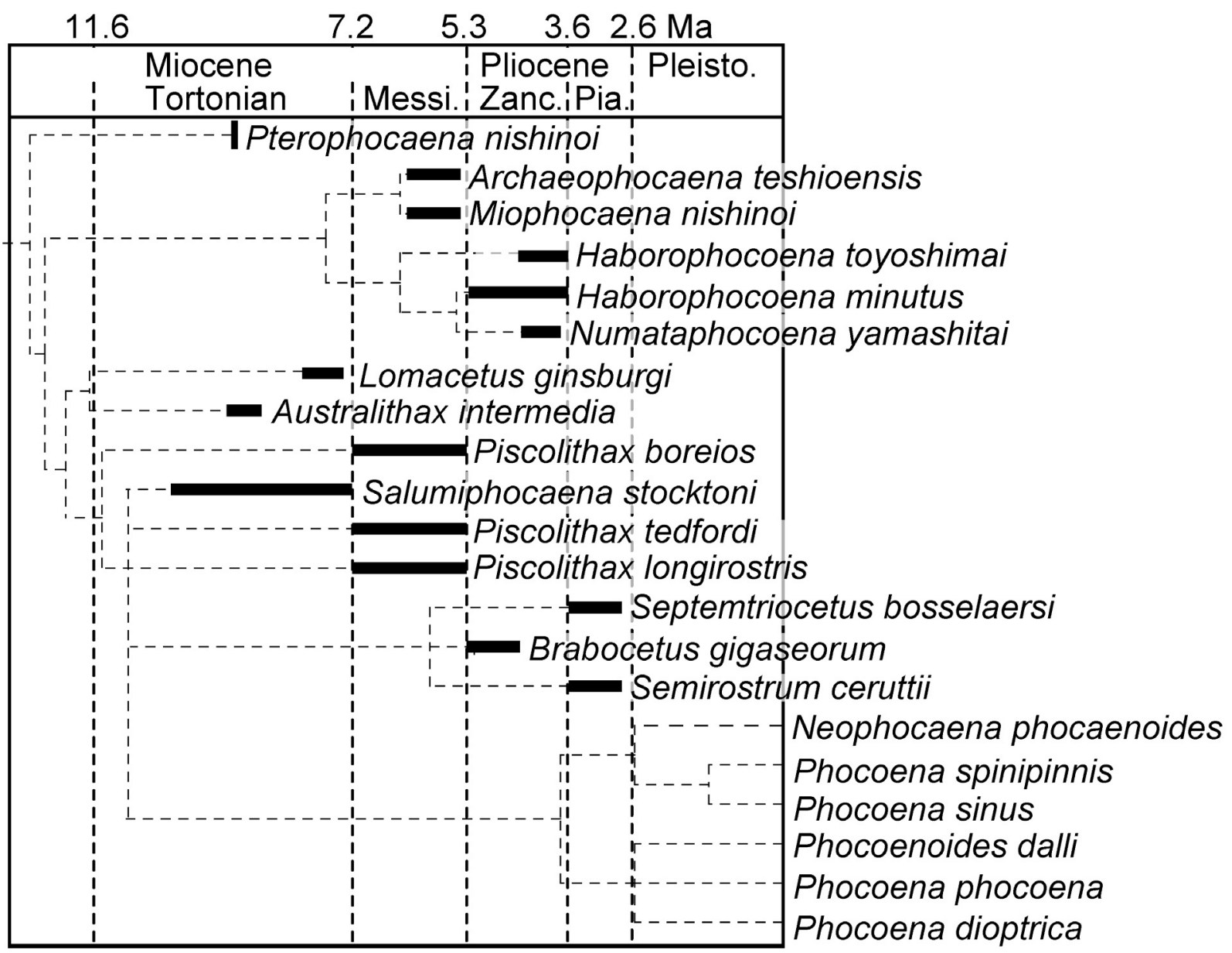

FIGURE 9. Geochronological distributions and postulated phylogeny of the Phocoenidae.

The branching pattern of fossil phocoenids from Hokkaido in previous works required the unnecessarily long ghost lineages in each branch (Murakami et al., 2012a, 2012b, 2014). Now, the phocoenids from Hokkaido as a clade makes the branching hypothesis of phocoenids highly valid based on parsimonious recognition because of minimizing a geological range of ghost linages of each branch (Figure 9). Although the phocoenids from Hokkaido are geologically younger in age, early Pliocene, than those from the Northeastern Pacific and the Atlantic such as the early late Miocene Lomacetus, Australithax and Salumiphocaena, and Piscolithax spp. from the latest Miocene, the former species have been recognized as being earlier diverging. The new branching pattern in this study shows that the common ancestor of the two subgroups appeared before the early late Miocene, based on the topology and the oldest known records of each subgroup. Moreover, our analyses revealed that the fossil phocoenids from Hokkaido was unrelated to the extant clade.

This study uses larger numbers of taxa and characters than Colpaert et al. (2015). The results of Colpaert et al. (2015) and our study show a similar pattern in terms of recognizing two subclades, rather than having a pectinate topology. In the Colpaert et al. (2015), the fossil phocoenids from Hokkaido were in a clade with Semirostrum. But, in our result, Semirostrum is placed among the unresolved polytomy, which is outside of the clade of fossil phocoenids from Hokkaido.

\section{Phylogenetic Relationships and Morphologies of Numataphocoena yamashitai and Haborophocoena spp}

Numataphocoena yamashitai and Haborophocoena minutus are located in the clade of phocoenids from Hokkaido, which is supported by two synapomorphies, that is, the relatively large exposure of the lacrimojugal in ventral view (between 
$62 \%$ and $69 \%$ of anteroposterior distance from antorbital notch to postorbital ridge, (Character 15) and narrow premaxillae at the level of the antorbital notch (Character 21). Haborophocoena toyoshimai is sister to the clade containing Numataphocoena yamashitai + Haborophocoena minutus. The three species is supported by one synapomorphy: flat (not bent) posterior process of the periotic in lateral view (Character 84).

The genus Haborophocoena is paraphyletic in the result of this study and also previous studies, which included the two species of Haborophocoena. Some studies found Haborophocoena minutus into a clade with later branching phocoenids and the extant phocoenids (Murakami et al., 2012a, 2012b, 2014, 2015; Tanaka and Fordyce, 2015). Colpaert et al. (2015) found Haborophocoena minutus in a clade with Archaeophocaena + Miophocaena + Semirostrum clade.

The character state shared only between the two species of Haborophocoena but not with Numataphocoena is having narrow mandibular fossae of the squamosals (Character 112). Numataphocoena yamashitai shows a wider mandibular fossa of the squamosal, which receives the mandibular condyle. This character is changed in the two lineages independently in this analysis, and might be related with mandibular movement and/or feeding styles. The preserved posterior left mandible of Haborophocoena toyoshimai shows a wider and more tilted clockwise mandibular condyle, compared to Phocoena phocoena, which has a narrower mandibular condyle. Numataphocoena yamashitai does not preserve the mandibular condyle. In short, these mandibular variations among the three species suggest that they might have different feeding ecology.

\section{CONCLUSION}

The new referred skull (NFL 2074) of Numataphocoena yamashitai from the upper part of the Horokaoshirarika Formation (early Pliocene), Numata, Hokkaido, Japan, adds diagnostic characters of the species, recognizes variations among the species and reveals the phylogenetic position among the Phocoenidae. Our cladistic analysis places Numataphocoena yamashitai adjacent to Haborophocoena toyoshimai and Haborophocoena minutus, among a clade of early branching phocoenids, all of which are chronologically and geographically close to each other, being all from Hokkaido. Numataphocoena yamashitai differs from other phocoenids in having a maxillary ter- race, narrower and sharper anterior part of the internal acoustic meatus, and a robust anterior process of the periotic. NFL 2074, which is about $80 \%$ size of the holotype, NFL 7 , is probably younger than the physically mature holotype. NFL 2074 does not have a well-developed nuchal crest like the holotype skull, which is probably the result of intraspecific variation.

\section{ACKNOWLEDGMENTS}

We thank R. Nakashima (National Institute of Advanced Industrial Science and Technology) for deposition of the specimen. We thank T. Shinmura (Ashoro Fossil Museum) for providing the restoration of Numataphocoena yamashitai. We thank R. Racicot (Howard University) and R. Boessenecker (College of Charleston) for giving constructive comments through reviewing, which improved the manuscript. Thanks go to O. Lambert (Institut royal des Sciences naturelles de Belgique), Racicot (HU) and M. Murakami (Shumei University) for giving helpful suggestions for our previous version of this manuscript. Thanks also go to M. Kimura (Numata, Fossil Museum, Hokkaido University of Education) and the Numata Kosei Clinic for encouragement to our research. The first author thanks to R.E. Fordyce (University of Otago) for discussion about the morphological characters, and N. Kohno (National Museum of Nature and Science), S. Shinohara (Numata Fossil Museum) and Murakami (Shumei University) for discussion on geology and chronology of phocoenids. We thank to H. Ito (National Research Institute of Fisheries Science, Fisheries Research Agency) for discussion about sexual dimorphisms on Stenella coeruleoalba, and H. Furusawa (Sapporo Museum Activity Center) for his permission to examine specimens stored in his institution for comparison.

\section{REFERENCES}

Aguirre-Fernández, G., Barnes, L.G., Aranda-Manteca, F.J., and Fernández-Rivera, J.R. 2009. Protoglobicephala mexicana, a new genus and species of Pliocene fossil dolphin (Cetacea; Odontoceti; Delphinidae) from the Gulf of California, Mexico. Boletin de la Sociedad Geologica Mexicana, 61:245265.

Allen, G.M. 1923. The black finless porpoise, Meomeris. Bulletin of the Museum of Comparative Zoology, 65:233-256.

Arnold, P.W. and Heinsohn, G.E. 1996. Phylogenetic status of the Irrawaddy dolphin Orcaella brevirostris (Owen in Gray): a cladistic analysis. Memoirs of the Queensland Museum, 39:141-204. 
Barnes, L.G. 1984a. Fossil odontocetes (Mammalia: Cetacea) from the Almejas Formation, Isla Cedros, Mexico. Paleobios, 42:1-46.

Barnes, L.G. 1984b. Whales, dolphins and porpoises; origin and evolution of the Cetacea, p. 139-158. In Gingerich, P.D. and Badgle, C.E. (eds.), Mammals. Notes for a Short Course, University of Tennessee, Department of Geological Science.

Barnes, L.G. 1985a. Evolution, taxonomy and antitropical distributions of the porpoises (Phocoenidae, Mammalia). Marine Mammal Science, 1:149-165.

Barnes, L.G. 1985b. Fossil pontoporiid dolphins (Mammalia: Cetacea) from the Pacific coast of North America. Contributions to Science, Natural History Museum of Los Angeles County, 363:1-34.

Barnes, L.G. 1990. The fossil record and evolutionary relationships of the genus Tursiops, p. 3-26. In Leatherwood, S. and Reeves, R.R. (eds.), The Bottlenose Dolphin. Academic Press Inc., San Diego, New York.

Bianucci, G. 2005. Arimidelphis sorbinii a new small killer whale-like dolphin from the Pliocene of Marecchia River (Central eastern Italy) and a phylogenetic analysis of the Orcininae (Cetacea: Odontoceti). Rivista Italiana di Paleontologia e Stratigrafia, 111:329-344.

Boessenecker, R.W. 2013. A new marine vertebrate assemblage from the Late Neogene Purisima Formation in Central California, part II: Pinnipeds and Cetaceans. Geodiversitas, 35:815-940.

Brisson, A. 1762. Regnum Animale in Classes IX distributum sive synopsis methodica. Edito altero auctior. Theodorum Haak, Leiden, 296.

Burmeister, G. 1885. Examen crítico de los mamíferos y reptiles fósiles denominados por D. Augusto Bravard y mencionados en su obra precedente, Anales del Museo Nacional de Buenos Aires, p. 95-174.

Colpaert, W., Bosselaers, M., and Lambert, O. 2015. Out of the Pacific: a second fossil porpoise from the Pliocene of the North Sea Basin. Acta Paleontologica Polonica, 60:1-10.

Curry, B.E. 1992. Facial anatomy and potential function of facial structures for sound production in the harbor porpoise (Phocoena phocoena) and Dall's porpoise (Phocoenoides dalli). Canadian Journal of Zoology, 70:2103-2114.

de Muizon, C. 1983. Un nouveau Phocoenidae (Cetacea) du Pliocène inférieur du Pérou. Comptes Rendus de l'Académie des Sciences, Paris, Série II, 296:1203-1206.

de Muizon, C. 1984. Les vertébrés fossiles de la Formation Pisco (Pérou). deuxiéme partie: les Odontocétes (Cetacea, Mammalia) du Pliocéne inférieur de SudSacaco. Travaux de l'Institut Français d'Études Andines, 27:1-188.

de Muizon, C. 1985. Nouvelles données sur le diphylétisme des Dauphins de rivière (Odontoceti, Cetacea, Mammalia). Comptes Rendus l'Academie des Sciences series 2, 301:359-362.

de Muizon, C. 1987. The affinities of Notocetus vanbenedeni, an Early Miocene platanistoid (Cetacea, Mam- malia) from Patagonia, southern Argentina. American Museum Novitates, 2904:1-27.

de Muizon, C. 1988. Les relations phylogenetiques des Delphinida (Cetacea, Mammalia). Annales de Paléontologie, 74:159-227.

de Muizon, C. 1991. A new Ziphiidae (Cetacea) from the Early Miocene of Washington State (USA) and phylogenetic analysis of the major groups of odontocetes. Bulletin du Muséum National d'Histoire Naturelle, 12:279-326.

de Muizon, C. 1994. Are the squalodonts related to the platanistoids? Proceedings of the San Diego Society of Natural History, 29:135-146.

De Smet, W.M.A. 1977. The regions of the cetacean vertebral column volume 3, p. 59-80. In Harrison, R.J. (ed.), Functional Anatomy of Marine Mammals. Academic Press, London.

Fajardo-Mellor, L., Berta, A., Brownell, R.L., Boy, C.C., and Goodall, N.P. 2006. The phylogenetic relationships and biogeography of true porpoises (Mammalia: Phocoenidae) based on morphological data. Marine Mammal Science, 22:910-932.

Flower, W.H. 1867. Description of the skeleton of Inia geoffrensis and the skull of Pontoporia blainvillii, with remarks on the systematic position of these animals in the Order Cetacea. Transactions of the Zoological Society of London, 6:87-116.

Flower, W.H. 1884. On the characters and divisions of the Family Delphinidae. Proceedings of the Zoological Society of London, 1883:466-513.

Fordyce, R.E. 1989. Origins and evolution of Antarctic marine mammals. Origins and Evolution of the Antarctic Biota, Geological Society Special Publiation, 47:269-281.

Fordyce, R.E. 1994. Waipatia maerewhenua, new genus and new species (Waipatiidae, new family), an archaic Late Oligocene dolphin (Cetacea: Odontoceti: Platanistoidea) from New Zealand. Proceedings of the San Diego Society of Natural History, 29:147176.

Fordyce, R.E. 2002. Simocetus rayi (Odontoceti: Simocetidae, new family): A bizarre new archaic Oligocene dolphin from the eastern North Pacific. Smithsonian Contributions to Paleobiology, 93:185222.

Fordyce, R.E. and de Muizon, C. 2001. Evolutionary history of whales: a review, p. 169-234 In Mazin, J.-M. and de Buffrenil, V. (eds.), Secondary Adaptation of Tetrapods to Life in Water. Pfeil, München, Germany.

Fordyce, R.E., Quilty, P.G., and Daniels, J. 2002. Australodelphis mirus, a bizarre new toothless ziphild-like fossil dolphin (Cetacea : Delphinidae) from the Pliocene of Vestfold Hills, East Antarctica. Antarctic Science, 14:37-54.

Fraser, F.C. and Purves, P.E. 1960. Hearing in cetaceans: evolution of the accessory air sacs and the structure of the outer and middle ear in recent cetaceans. Bulletin of the British Museum of Natural History (Zoology) 7:1-140. 
Geisler, J.H., Godfrey, S.J., and Lambert, O. 2012. A new genus and species of late Miocene inioid (Cetacea, Odontoceti) from the Meherrin River, North Carolina, USA. Journal of Vertebrate Paleontology, 32:198-211.

Geisler, J.H., McGowen, M.R., Yang, G., and Gatesy, J. 2011. A supermatrix analysis of genomic, morphological, and paleontological data from crown Cetacea. BMC Evolutionary Biology, 11:1-33.

Geisler, J.H. and Sanders, A.E. 2003. Morphological evidence for the phylogeny of Cetacea. Journal of Mammalian Evolution, 10:23-129.

Goloboff, P.A., Farris, J.S., and Nixon, K.C. 2008. TNT, a free program for phylogenetic analysis. Cladistics, 24:774-786.

Gray, J.E. 1825. An outline of an attempt at the disposition of Mammalia into tribes and families, with a list of the genera apparently appertaining to each tribe. Philosophical Annals, 26:337-344.

Heyning, J.E. 1989. Comparative facial anatomy of beaked whales (Ziphiidae) and a systematic revision among the families of extant Odontoceti. Contributions in Science, Natural History Museum of Los Angeles County., 405:1-64.

Heyning, J.E. 1997. Sperm whale phylogeny revisited: analysis of the morphological evidence. Marine Mammal Science, 13:596-613.

Ichishima, H. 2011. Do cetaceans have the mesethmoid? Memoir of the Fukui Prefectural Dinosaur Museum, 10:63-75.

Ichishima, H. and Kimura, M. 2000. A new fossil porpoise (Cetacea: Delphinoidea: Phocoenidae) from the Early Pliocene Horokaoshirarika Formation, Hokkaido, Japan. Journal of Vertebrate Paleontology, 20:561-576.

Ichishima, H. and Kimura, M. 2005. Haborophocoena toyoshimai, a new Early Pliocene porpoise (Cetacea; Phocoenidae) from Hokkaido, Japan. Journal of Vertebrate Paleontology, 25:655-664.

Ichishima, H. and Kimura, M. 2009. A new species of Haborophocoena, an Early Pliocene phocoenid cetacean from Hokkaido, Japan. Marine Mammal Science, 25:855-874.

Ichishima, H. and Kimura, M. 2013. New material of Haborophocoena toyoshimai (Odontoceti: Phocoenidae) from the lower Pliocene Embetsu Formation of Hokkaido, Japan. Paleontological Research, 17:127137.

Ito, H. and Miyazaki, N. 1990. Skeletal development of the striped dolphin (Stenella coeruleoalba) in Japanese waters. Journal of the Mammalogical Society of Japan, 14:79-96.

Kasuya, T. 1973. Systematic consideration of recent toothed whales based on the morphology of tympano-periotic bone. Scientific Reports of the Whales Research Institute, Tokyo, 25:1-103.

Kobayashi, I., Hata, M., Yamaguchi, S., and Kakimi, T. 1969. Geology of the Moseushi district. Quadrangle series scale 1:50,000, Asahikawa (3). Geological Survey of Japan, Kawasaki, Japan.

Kohno, N., Tomida, Y., Hasegawa, Y., and Furusawa, H. 1995. Pliocene tusked odobenids (Mammalia: Carnivora) in the western North Pacific, and their paleobiogeography. Bulletin-National Science Museum Tokyo Series C, 21:111-130.

Lambert, O. 2005. Phylogenetic affinities of the longsnouted dolphin Eurhinodelphis (Cetacea, Odontoceti) from the Miocene of Antwerp, Belgium. Palaeontology, 48:653-679.

Lambert, O. 2008. A new porpoise (Cetacea, Odontoceti, Phocoenidae) from the Pliocene of the North Sea. Journal of Vertebrate Paleontology, 28:863-872.

Luo, Z. and Marsh, K. 1996. Petrosal (periotic) and inner ear of a Pliocene kogiine whale (Kogiinae, Odontoceti): implications on relationships and hearing evolution of toothed whales. Journal of Vertebrate Paleontology, 16:328-348.

Maddison, W.P. and Maddison, D.R. 2011. Mesquite: a modular system for evolutionary analysis. Available at http://mesquiteproject.org.

Marsh, H., Lloze, R., Heinsohn, G.E., and Kasuya, T. 1989. Irrawaddy dolphin - Orcaella brevirostris, (Gray, 1866), p. 101-118. In Ridgway, S.H. and Harrison, S. (eds.), Handbook of Marine Mammals. Volume 4: River Dolphins and the Larger Toothed Whales.

Mead, J.G. 1975. Anatomy of the external nasal passages and facial complex in the Delphinidae (Mammalia, Cetacea). Smithsonian Contributions to Zoology, 207:1-72.

Mead, J.G. and Fordyce, R.E. 2009. The therian skull: a lexicon with emphasis on the odontocetes. Smithsonian Contributions to Zoology, 627:1-248.

Messenger, S.L. and McGuire, J.A. 1998. Morphology, molecules, and the phylogenetics of cetaceans. Systematic Biology, 47:90-124.

Miller, G.S. 1923. The telescoping of the cetacean skull. Smithsonian Miscellaneous Collections, 76:1-70.

Murakami, M., Shimada, C., Hikida, Y., and Hirano, H. 2012a. A new basal porpoise, Pterophocaena nishinoi (Cetacea, Odontoceti, Delphinoidea), from the upper Miocene of Japan and its phylogenetic relationships. Journal of Vertebrate Paleontology, 32:1157-1171.

Murakami, M., Shimada, C., Hikida, Y., and Hirano, H. 2012b. Two new extinct basal phocoenids (Cetacea, Odontoceti, Delphinoidea), from the upper Miocene Koetoi Formation of Japan and their phylogenetic significance. Journal of Vertebrate Paleontology, 32:1172-1185.

Murakami, M., Shimada, C., Hikida, Y., and Hirano, H. 2015. New fossil remains from the Pliocene Koetoi Formation of northern Japan provide insights into growth rates and the vertebral evolution of porpoises. Acta Palaeontologica Polonica, 60:97-111.

Murakami, M., Shimada, C., Hikida, Y., Soeda, Y., and Hirano, H. 2014. Eodelphis kabatensis, a new name 
for the oldest true dolphin Stenella kabatensis Horikawa, 1977 (Cetacea, Odontoceti, Delphinidae), from the upper Miocene of Japan, and the phylogeny and paleobiogeography of Delphinoidea. Journal of Vertebrate Paleontology, 34:491-511.

Nakashima, R. and Majima, R. 2000. The nature of shell beds in the inner-shelf deposits-A case study of the upper Miocene to lower Pliocene Horokaoshirarika Formation in central Hokkaido. Journal of Geological Society of Japan (Chishitsugakuzassi), 106:136-150. (In Japanese with English abstract)

Nakashima, R. and Watanabe, M. 2000. First occurrence age of Fortipecten takahashii (Yokoyama) (Bivalvia: Pectinidae) from the lower part of the upper Miocene Horokaoshirarika Formation in Numata-cho, central Hokkaido. The Journal of the Geological Society of Japan, 106:578-581. (In Japanese with English abstract)

Noble, B. and Fraser, F. 1971. Description of a skeleton and supplementary notes on the skull of a rare porpoise Phocoena sinus Norris \& McFarland 1958. Journal of Natural History, 5:447-464.

Racicot, R.A., Deméré, T.A., Beatty, B.L., and Boessenecker, R.W. 2014. Unique feeding morphology in a new prognathous extinct porpoise from the Pliocene of California. Current Biology, 24:774-779.

Rommel, S. 1990. Osteology of the bottlenose dolphin, p. 29-49. In Leatherwood, S. and Reeves, R.R. (eds.), The Bottlenose Dolphin. Academic Press Inc, San Diego, New York.

Sanders, A.E. and Barnes, L.G. 2002. Paleontology of the late Oligocene Ashley and Chandler Bridge formations of South Carolina, 2: Micromysticetus rothauseni, a primitive cetotheriid mysticete (Mammalia: Cetacea). Smithsonian Contributions to Paleobiology, 93:271-293.

Tanaka, Y. 2016. A new and ontogenetically younger specimen of Numataphocoena yamashitai from the lower Pliocene, the upper part of the Horokaoshirarika Formation, Numata, Hokkaido, Japan. Paleontological Research, 20:105-115.
Tanaka, Y. and Fordyce, R.E. 2014. Fossil dolphin Otekaikea marplesi (latest Oligocene, New Zealand) expands the morphological and taxonomic diversity of Oligocene cetaceans. PLoS ONE, 9:e107972.

Tanaka, Y. and Fordyce, R.E. 2015. A new Oligo-Miocene dolphin from New Zealand: Otekaikea huata expands diversity of the early Platanistoidea. Palaeontologia Electronica, 18(2.23A):1-71.

Tomida, Y. and Kohno, N. 1992. Fossil marine mammals from the Koetoi Formation (Middle Late Miocene to Early Pliocene) in Wakkanai City, northern Hokkaido, Japan. Memoirs of the National Science Museum (Tokyo), 25:49-56.

Uhen, M.D., Fordyce, R.E., and Barnes, L.G. 2008. Odontoceti, p. 566-606. In Janis, C.M., Gunnell, G.R., and Uhen, M.D. (eds.), Evolution of Tertiary Mammals of North America, 2. Cambridge University Press, Cambridge.

Wada, N., Ganzawa, Y., Sagayama, T., Takahashi, K., Gocho, M., Watanabe, N., and Akiyama, M. 1986. Stratigraphy and age determination of the pliocene in the Rumoi-Fukagawa district, Hokkaido, Japan, The 93th Annual Meeting of the Geological Society of Japan, p. 142,(In Japanese)

Watanabe, M. and Yoshida, F. 1995. Geology of the Ebishima District. Quadrangle series scale 1:50,000, Asahikawa (3). Geological Survey of Japan, Tsukuba, Japan.

Whitmore, F.C. and Sanders, A.E. 1977. Review of the Oligocene Cetacea. Systematic Zoology, 25:304320.

Wilson, L.E. 1973. A delphinid (Mammalia, Cetacea) from the Miocene of Palos Verdes Hills, California. University of California Publications in Geological Sciences, 103:1-34.

Yamashita, S. and Kimura, M. 1990. Occurrence of Early Pliocene otariid fossil in Numata-cho, Hokkaido. Earth Science (Chikyu Kagaku) 44:53-60.(In Japanese with English abstract) 


\section{APPENDIX 1.}

Cladistic matrix of Tanaka and Ichishima (2016) in nexus format. Available in zipped format with Appendix 2 and Appendix 5 online at palaeo-electronica.org/content/2016/1663-a-new-skull-of-numataphocoena

\section{APPENDIX 2}

Cladistic matrix of Tanaka and Ichishima (2016) in TNT format. Available in zipped format with Appendix 1and Appendix 5 online at palaeo-electronica.org/content/2016/1663-a-new-skull-of-numataphocoena 


\section{APPENDIX 3.}

Morphological characters used in the phylogenetic analysis.

Terminology generally follows that of the cladistic papers cited, which in a few cases does not agree with the recommended uses of Mead and Fordyce (2009). For each character, references are given for the main past uses, with the relevant published character number given with a hatch \# thus: Murakami et al. (2012a) \#1.

\section{Rostrum, Dental, and Mandibular}

(1) Length of rostrum as percent skull length: moderately long, 50-55\% (0); long, 55-60\% (1); very long, $>60 \%$ (2); medium, 50-40\% (3); very short, 40$35 \%$ (4). (Murakami et al. (2012a, 2012b) \#1; modified from Arnold and Heinsohn (1996) \#8; Bianucci (2005) \#1; Lambert (2008) \#1; Tanaka and Fordyce (2014, 2015) \#1).

(2) Premaxillae transverse proportion: transversely inflated almost entire length of rostrum (0); flat almost entire length of the rostrum (1). (Murakami et al. (2012a, 2012b) \#2; Tanaka and Fordyce (2014, 2015) \#2).

(3) Premaxillae mediolateral proportion: not compressed mediolaterally (0); compressed mediolaterally at anterior of rostrum (1). (Murakami et al. (2012a, 2012b) \#3; Tanaka and Fordyce $(2014,2015)$ \#3).

(4) Premaxillae at apex of rostrum: with lateral margins parallel or diverging (0); narrowing (1). (Murakami et al. (2012a, 2012b) \#4; modified from Bianucci (2005) \#2; Tanaka and Fordyce $(2014,2015)$ \#4).

(5) Mesorostral groove constricted posteriorly, anterior to the nares and behind the level of the antorbital notch, then rapidly diverging anteriorly: absent (0); present (1). (modified from Murakami et al. (2012b) \#279; Tanaka and Fordyce $(2014,2015)$ \#7).

(6) Lateral margin of rostrum anterior to maxillary flange: concave (0); straight (1); convex (2); absent (3) (Murakami et al. (2012a, 2012b) \#7; modified from Bianucci (2005) \#3; Tanaka and Fordyce (2014, 2015) \#8).

(7) Antorbital notch: absent or weakly developed (0); well developed (1). (Messenger and McGuire (1998) \#1426; Fajardo-Mellor et al. (2006) \#6; Murakami et al. (2012a, 2012b) \#9; Tanaka and Fordyce (2014, 2015) \#10).

(8) Width of premaxillae at mid-rostrum as percent greatest width of maxillae at level of postorbital processes: wide, $>25 \%$ (0); medium, 25-15\% (1); narrow, <15\% (2). (Murakami et al. (2012a, 2012b) \#10; modified from Aguirre-Fernandez et al. (2009) \#4); Tanaka and Fordyce $(2014,2015)$ \#11)

(9) Width of rostrum at mid-length as percent greatest width of maxillae at level of postorbital processes: wide, $>35 \%$ (0); medium, 35-30\% (1); narrow,
$<30 \%$ (2). (Murakami et al. (2012a, 2012b) \#11; modified from Aguirre-Fernandez et al. (2009) \#6; Tanaka and Fordyce $(2014,2015)$ \#12).

(10) Anterior sinus fossa: absent (0); between anterior extremity of pterygoid sinus and posterior extremity of upper tooth row (1); between posterior extremity of upper tooth row and midpoint of rostrum (2); beyond midpoint of rostrum (3). (Murakami et al. (2012a, 2012b) \#17; modified from Muizon (1988); Barnes (1990); Bianucci (2005) \#13; Arnold and Heinsohn (1996) \#21; Geisler and Sanders (2003) \#157; Aguirre-Fernandez et al. (2009) \#18; Geisler et al. (2011) (2012) \#157; derived from Fraser and Purves (1960); Tanaka and Fordyce (2014, 2015) \#18).

\section{Teeth}

(11) Teeth: conical, with or without accessory cusp (0); spatulate (1). (Murakami et al. (2012a, 2012b) \#21; modified from Heyning (1989) \#40 (1997) \#72; Arnold and Heinsohn (1996) \#25; Messenger and McGuire (1998) \#1470; Geisler and Sanders (2003) \#27 (2012) \#27; Lambert (2008) \#16; Geisler et al. (2011) \#27; derived from Barnes (1984a); modified from Tanaka and Fordyce $(2014,2015)$ \#21).

(12) Upper anterior "teeth": about same size as upper posterior teeth (0); clearly smaller than upper posterior teeth or absent (1). (Murakami et al. (2012a, 2012b) \#22; modified from Tanaka and Fordyce (2014, 2015) \#22).

(13) Greatest diameter of largest functional tooth as percent of greatest width of maxillae at the level of the postorbital processes: medium, 5-3\% (0); small, $<3 \%$ (1) (Murakami et al. (2012a, 2012b) \#25; Aguirre-Fernandez et al. (2009) \#15; modified from Tanaka and Fordyce $(2014,2015)$ \#25).

\section{Orbit}

(14) Antorbital process shape in dorsal view: squared (0); rounded (1); tapered (2), reduced (3). (Bianucci (2005) \#4; Murakami et al. (2012a, 2012b) \#34; modified from Tanaka and Fordyce $(2014,2015)$ \#34).

(15) Combined anteroposterior length of the lacrimal and jugal exposure that is posterior to antorbital notch: with skull in ventral view, exposure is small and combined length forms $<50 \%$ of anteroposterior distance from antorbital notch to postorbital ridge (0); intermediate, forms between 50 and $62 \%$ of that distance (1); large, forms between 62 and $69 \%$ that distance (2); very large, forms $>69 \%$ of that distance (3). (Murakami et al. in (2012a, 2012b) \#42; modified from Geisler and Sanders (2003) \#55; Geisler et al. (2012; 2011) \#55; Tanaka and Fordyce $(2014,2015) \# 42)$. 
(16) Dorsolateral edge of internal opening of infraorbital foramen: formed by maxilla (0); formed by maxilla and lacrimal and/or jugal (I); formed by lacrimal and/or jugal (2); formed by frontal (3). (Geisler and Sanders (2003) \#57; Geisler et al. (2011) (2012) \#57; Murakami et al. (2012a, 2012b) \#43; derived from Miller (1923) ; Tanaka and Fordyce (2014, 2015) \#43).

(17) Ventromedial edge of internal opening of infraorbital foramen: formed by maxilla (0); formed by maxilla and palatine and/or pterygoid (1); formed by palatine and/or pterygoid (2). (Geisler and Sanders (2003) \#58; Geisler et al. (2012; 2011) \#58; Murakami et al. (2012a, 2012b) \#44; derived from Miller (1923); Tanaka and Fordyce (2014, 2015) \#44).

(18) Direction of apex of postorbital process of frontal: projected posterolaterally and slightly ventrally $(0)$; directed ventrally (1); not clear because of extremely reduced process (2). (modified from Murakami et al. (2012a, 2012b) \#46; Geisler and Sanders (2003) \#61; Geisler et al. (2012; 2011) \#61; Tanaka and Fordyce $(2014,2015)$ \#46).

(19) Shape of postorbital process of frontal: triangular, trapezoidal, or an anteroposteriorly widened falciform (0); dorsoventrally long falciform (1); robust, blunt descending posteriorly (2). (modified from Murakami et al. (2012a, 2012b) \#47; Tanaka and Fordyce $(2014,2015)$ \#47).

\section{Facial Region}

(20) Anterior dorsal infraorbital foramina: two (0); three or more (1). (Murakami et al. (2012a, 2012b) \#49; modified from Barnes (1984b); Geisler and Sanders (2003) \#64; Geisler et al. (2011) \#64 (2012) \#64; Tanaka and Fordyce $(2014,2015)$ \#49).

(21) Width of premaxillae at antorbital notches as percent width of rostrum at antorbital notch: narrow, $<49 \%$ (0); moderate, 50-64\% (1); wide, >65\% (2); antorbital notch absent (3). (Geisler and Sanders (2003) \#66; Geisler et al. (2011)\#66 (2012) \#66; modified from Murakami et al. (2012a, 2012b) \#51; Tanaka and Fordyce $(2014,2015)$ \#51).

(22) Premaxillary foramen locating: medial (0); midpoint to lateral (1) absent (2). (modified from Murakami et al. (Murakami et al., 2014): Murakami et al. (2012b) \#280; Tanaka and Fordyce $(2014,2015)$ \#55).

(23) Lateral margin of the right premaxilla posterior to premaxillary foramen: widen posteriorly (0); straight (1). (Murakami et al. (2012b) \#281; Tanaka and Fordyce $(2014,2015)$ \#56).

(24) Posterolateral sulcus: deep (0); shallow or absent (1); presence of additional posterolateral sulcus (longitudinal striation) (2). (Murakami et al. (2012a, 2012b) \#55; modified from Muizon (1984, 1988); Lambert (2008) \#6; Geisler and Sanders (2003) \#72; Geisler et al. (2011) (2012) \#72; Tanaka and Fordyce $(2014,2015)$ \#57).
(25) Posterior projections of premaxillae: both premaxillae extending posterior to anterior tip of nasals (0); neither premaxillae extending beyond external nares, and premaxillae displaced laterally by medial projection of maxilla (1); neither premaxillae extending posterior to external nares, and narrow posterior end of premaxillae adjacent to external nares (2); only right premaxilla extending beyond or in line with anterior-most portion of nasals (3). (Murakami et al. (2012a, 2012b) \#76; modified from Muizon (1984); Barnes (1985a); Heyning (1989) \#39, 42 (1997) \#63, 71, 74; Arnold and Heinsohn,(1996) \#35; Messenger and McGuire (1998) \#1407, 1408; Fajardo-Mellor et al. (2006) \#3; Lambert (2008) \#5; Fordyce (1994) \#27; Tanaka and Fordyce $(2014,2015)$ \#58).

(26) Maxilla on dorsal surface of skull: does not contact supraoccipital posteriorly, maxilla separated by frontal and/or parietal (0); contact present (1). (Geisler and Sanders (2003) \#129; Geisler et al. (2011) \#129 (2012) \#129, modified from Muizon (1991) (1994); Murakami et al. (2012a, 2012b) \#60; Tanaka and Fordyce $(2014,2015)$ \#62).

(27) Anterolateral corner of maxilla overlying supraorbital process of frontal: thin and equal in thickness to parts posteromedial (0); thickened with thinner maxilla in posteromedial direction (1). (Geisler and Sanders (2003) \#78; Geisler et al. (2011) \#78 (2012) \#78; Murakami et al. (2012a, 2012b) \#62; Tanaka and Fordyce $(2014,2015)$ \#64).

(28) Maxillary crest on supraorbital process of maxilla: longitudinal ridges absent except at lateral edge of antorbital process (0); presence of longitudinal ridge except at lateral edge of antorbital process (1); longitudinal ridge present and joined with maxillary flange (2); presence of transversely compressed high crest, except at lateral edge of antorbital process (3); absent (4). (Murakami et al. (2012a, 2012b) \#64; modified from Muizon (1984) (1987); Barnes (1985b); Messenger and McGuire (1998) \#1420; Geisler and Sanders (2003) \#79; Geisler et al. (2011) \#79 (2012) \#79; derived from Miller (1923); Tanaka and Fordyce (2014, 2015) \#66).

(29) Fossa for inferior vestibule on maxilla lateral to external nares or lateral to premaxilla: absent $(0)$; present (1). (Muizon (1988); Murakami et al. (2012a, 2012b) \#68; derived from Curry (1992); Tanaka and Fordyce $(2014,2015)$ \#70).

(30) Maxillary intrusion, anterior to external nares and encroaching the posteromedial or medial face of each premaxilla: absent (0); maxilla visible within opened mesorostral canal as small exposure medially (1); exposure of maxilla reaches dorsally to level of premaxilla and forms a square, rectangular to triangular plate (2); exposure of maxilla reaches dorsally and forms a small subcircular to polygonal ossicle (3). (Muizon (1984) (1988); Arnold and 
Heinsohn (1996) \#24; Messenger and McGuire (1998) \#1422; Murakami et al. (2012a, 2012b) \#69; Tanaka and Fordyce $(2014,2015)$ \#71).

(31) Premaxillary crest or posterior maxillary crest adjacent to nasal: absent (0); present (1). (transverse premaxillary crest, sensu Lambert (2005) \#6; Murakami et al. (2012a, 2012b) \#70; Tanaka and Fordyce (2014, 2015) \#72).

(32) Premaxilla: not overhanging itself or maxilla laterally (0); overhanging itself or maxilla laterally, from anterior to midpoint of external nares (1). (Murakami et al. (2012a, 2012b) \#71; Tanaka and Fordyce (2014, 2015) \#73).

(33) Premaxillary sac fossa: smooth (0); rugose (1). (Messenger and McGuire (1998) \#1551; Murakami et al. (2012a, 2012b) \#72; Tanaka and Fordyce (2014, 2015) \#74).

(34) Ratio of width of right premaxilla to width of left premaxilla in line with midpoint of external nares: 0.90-1.19 (0); 1.20-1.50 (1); 1.50> (2). (Murakami et al. (2012a, 2012b) \#73; Tanaka and Fordyce (2014, 2015) \#75).

(35) Ratio of greatest width of premaxillae to greatest width of maxillae at level of postorbital processes: $\geq 0.50$ (0); 0.49-0.38 (1); <0.38 (2). (Murakami et al. (2012a, 2012b) \#74; Tanaka and Fordyce (2014, 2015) \#76).

(36) Premaxillary eminence: absent (0); present but low (1); present and high (2). (Lambert (2008) \#4; Murakami et al. (2012a, 2012b) \#75; modified from Muizon (1984); Barnes (1985a); Heyning (1989) \#36 (1997) \#68; Arnold and Heinsohn (1996) \#12; Messenger and McGuire (1998) \#1410; Geisler and Sanders (2003); \#68; Fajardo-Mellor et al. (2006) \#2; Geisler et al. (2011) \#68 (2012) \#69; derived from Flower (1867); Noble and Fraser (1971) ; Tanaka and Fordyce $(2014,2015)$ \#77).

(37) Mesethmoid: not expanded posterodorsally (0); extended posterodorsally but narrow (1); expanded posterodorsally and visible in lateral view (2). (Murakami et al. (2012a, 2012b) \#81; modified from Muizon (1984, 1988); Messenger and McGuire (1998) \#1454; Bianucci (2005) \#9; Tanaka and Fordyce (2014, 2015) \#82).

\section{Vertex and Area Adjacent to the Nares}

(38) Nasals: lower than frontals (0); nearly same height as frontals (1); clearly higher than frontals (2). (Muizon (1988); Messenger and McGuire (1998) \#1434; Geisler and Sanders (2003); \#124; Geisler et al. (2011) \#124 (2012) \#124; Murakami et al. (2012a) \#86; Tanaka and Fordyce $(2014,2015)$ \#87).

(39) Nasal protuberance: absent (0); present (1). (Muizon (1988); Messenger and McGuire (1998) \#1433; Fajardo-Mellor et al. (2006) \#7; Lambert (2008) \#8; Murakami et al. (2012a, 2012b) \#87; Tanaka and Fordyce (2014, 2015) \#88).
(40) Both nasals: straight anterior edges in one transverse plane (0); with point on midline and gap on each side between premaxilla and nasal (1); concave posteriorly on midline and gap on each side between premaxilla and nasal (2); concave posteriorly on midline (3). (Murakami et al. (2012a, 2012b) \#88; modified from Geisler and Sanders (2003) \#116; Geisler et al. (2011) \#116 (2012) \#116; derived from Moore (1968); Tanaka and Fordyce (2014, 2015) \#89).

(41) Lateral edges of nasals: not overhanging or covering maxillae or premaxillae (0); overhanging or partly covering maxillae or premaxillae (1). (Murakami et al. (2012a, 2012b) \#92; Tanaka and Fordyce (2014, 2015) \#93).

(42) Nasal-frontal suture: anterior wedge (narial process) between frontal posterior ends of nasals (0); $\mathrm{W}$ or reversed $U$ suture line (1). (Murakami et al. (2012a, 2012b) \#93; modified from Muizon (1988); Geisler and Sanders (2003) \#121; Geisler et al. (2011) \#121 (2012) \#121; Tanaka and Fordyce (2014, 2015) \#94).

(43) Frontals posterior to nasals and between premaxillae: narrower than transverse width of nasals, maxillae expanded medially posterior to nasals (0); same as transverse width of nasals (1); wider than maximum transverse width across nasals (2). (Geisler and Sanders (2003) \#125; Geisler et al. (2011) \#125 (2012) \#125; Murakami et al. (2012a, 2012b) \#94; modified from Messenger and McGuire (1998) \#1457; Tanaka and Fordyce (2014, 2015) \#95).

(44) Frontal boss on vertex: absent (0); present (1). (Muizon (1984, 1988); Messenger and McGuire (1998) \#1461; Fajardo-Mellor et al. (2006) \#12; Murakami et al. (2012a, 2012b) \#95; modified from Lambert (2008) \#9; Tanaka and Fordyce $(2014,2015)$ \#96).

(45) Nuchal crest: below frontals and/or nasals (0); at same level as frontals and/or nasals (1). (Murakami et al. (2012a, 2012b) \#99; modified from Geisler and Sanders (2003) \#128; derived from Moore (1968); Tanaka and Fordyce $(2014,2015)$ \#100).

Temporal Fossae, Zygomatic Arch, and Occipitals

(46) Temporal fossa shape in lateral view: height lower than anteroposterior length (0); higher (1); lower and its posterior end is rounded (2). (Tanaka and Fordyce $(2014,2015)$ \#281)

(47) Temporal fossa: not roofed over by lateral expansion of maxillae (0); roofed over by lateral expansion of maxillae (1). (Muizon (1988); Heyning (1989) \#22 (1997) \#54; Arnold and Heinsohn (1996) \#39; Messenger and McGuire (1998) \#1453; Murakami et al. (2012a, 2012b) \#100; Tanaka and Fordyce $(2014,2015)$ \#101).

(48) Parietals in dorsal view: completely absent in skull roof (0); visible only as triangular areas, dorsolateral to supraoccipital, with non-overlapping supraoccipital separated from and contacting parietals 
along irregular suture (1). (Geisler and Sanders (2003) \#134; Geisler et al. (2011) \#134 (2012) \#134; Murakami et al. (2012a, 2012b) \#104; derived from Whitmore and Sanders (1977); Barnes (1990); modified from Lambert (2005) \#15; Tanaka and Fordyce $(2014,2015)$ \#105).

(49) Interparietal: present (0); absent or fused and therefore not distinguishable from parietals and frontals (1). (Geisler and Sanders (2003) \#135; Geisler et al. (2011) \#135 (2012) \#135; Murakami et al. (2012a) \#105; Tanaka and Fordyce (2014, 2015) \#106).

(50) Anterior zygomatic process end of squmosal in lateral view: taipered (0); squared (1). (Tanaka and Fordyce (2014, 2015) \#282)

(51) Zygomatic process of squamosal: directed anterolaterally (0); directed anteriorly (1). (Sanders and Barnes, 2002; Geisler and Sanders (2003) \#142; Geisler et al. (2011) \#142 (2012) \#142; Murakami et al. (2012a, 2012b) \#108; Tanaka and Fordyce (2014, 2015) \#109).

(52) Zygomatic process of squamosal in lateral view: part of dorsal face visible (0); entire dorsal surface of squamosal visible (1). (Murakami et al. (2012a, 2012b) \#109; Tanaka and Fordyce (2014, 2015) \#110).

(53) Emargination of posterior edge of zygomatic process by neck muscle fossa, skull in lateral view: deep emargination (0); shallow emargination (1). (Geisler and Sanders (2003) \#144; Geisler et al. (2011) \#144 (2012) \#144; Murakami et al. (2012a, 2012b) \#110; Tanaka and Fordyce (2014, 2015) \#111).

(54) Ventral edge of zygomatic process of squamosal in lateral view: concave (0); almost straight (1); convex (2). (Geisler and Sanders (2003); \#150; Geisler et al. (2011) \#150 (2012) \#150; Murakami et al. (2012a, 2012b) \#112).

(55) Postglenoid process of squamosal: not reduced (0); greatly reduced (1). (Murakami et al. (2012a, 2012b) \#113; Tanaka and Fordyce (2014, 2015) \#114).

(56) Postglenoid process in lateral view: tapering ventrally (0); squared off ventrally (1); same as state 1 except very wide anteroposterior diameter of process (2). (Geisler and Sanders (2003) \#151; Lambert (2005) \#24; Geisler et al. (2011) \#151 (2012) \#151; Murakami et al. (2012a, 2012b) \#114; derived from Muizon (1991) ; Tanaka and Fordyce (2014, 2015) \#115).

(57) Relative ventral projections of postglenoid and posttympanic processes of squamosal: postglenoid process more ventral or at same level as post-tympanic process (0); apex of postglenoid process dorsally higher than post-tympanic process (1). (Lambert (2005) \#25; Murakami et al. (2012a). b \#115; Tanaka and Fordyce $(2014,2015)$ \#116).
(58) Dorsal condyloid fossa: present, situated anterodorsal to dorsal edge of condyle (0); present and forming deep pit (1). (Geisler and Sanders (2003) \#156; Geisler et al. (2011) \#156 (2012) \#156; Murakami et al. (2012a, 2012b) \#118; derived from Sanders and Barnes (2002); Tanaka and Fordyce (2014, 2015) \#119).

\section{Anterior Basicranium}

(59) Lateral lamina of palatine relationship with orbit: does not form bony bridge "over" (= ventral to) orbit (0); does form bony bridge "over" (= ventral to) orbit (1). (Muizon (1984); Messenger and McGuire (1998) \#1444; Murakami et al. (2012a, 2012b) \#123; Tanaka and Fordyce $(2014,2015)$ \#124).

(60) Pterygoids in anteroventral view: separated from each other by posteroventrally elongated palatines and/or vomer (0); contacting entire length of hamular process (1); contacting each other partially (2). (Murakami et al. (2012a, 2012b) \#124; modified from Arnold and Heinsohn (1996) \#5; Messenger and McGuire (1998) \#1445; Fajardo-Mellor et al. (2006) \#9; derived from Flower (1884); Barnes (1985a); Marsh et al. (1989) ; Tanaka and Fordyce (2014, 2015) \#125).

(61) Lateral lamina of pterygoid: present and articulated with alisphenoid (0); partial, restricted to region lateral to hamular process (1). (Murakami et al. (2012a) \#126; modified from Arnold and Heinsohn (1996) \#121; Messenger and McGuire (1998) \#1446; Geisler and Sanders (2003) \#164; Lambert (2005) \#32; Geisler et al. (2011) \#164 (2012) \#164; derived from Miller (1923); Kellogg (1936); Fraser and Purves (1960) ; Tanaka and Fordyce (2014, 2015) \#127).

(62) Subtemporal crest: present (0); present but reduced, or absent (1). (modified from Geisler and Sanders (2003) \#165; Geisler et al. (2011) \#165 (2012) \#165; Murakami et al. (2012a, 2012b) \#127; Tanaka and Fordyce $(2014,2015)$ \#128).

(63) Superior lamina of pterygoid: absent from sphenoidal region but present in orbital region (0); present and covers most of ventral exposure of alisphenoid (1); partially absent from orbital region (2); completely absent from orbital region (3). (Murakami et al. (2012a, 2012b) \#128; modified from Arnold and Heinsohn (1996) \#16; Geisler and Sanders (2003) \#167; Geisler et al. (2011) \#167 (2012) \#167; derived from Miller (1923); Fraser and Purves (1960)) ; Tanaka and Fordyce $(2014,2015)$ \#129.

(64) Depth of pterygoid sinus fossa in basicranium: deep, and extended dorsally into orbit (0); deep, excavated dorsally to level of cranial foramen oval (1). (modified from Fordyce (1994) \#6; Lambert (2005) \#30; Murakami et al. (2012a, 2012b) \#130; Tanaka and Fordyce $(2014,2015)$ \#131).

(65) Anterior level of pterygoid sinus fossa: interrupted posterior to, or the level of, antorbital notch (0); 
extending beyond the level of the antorbital notch (1). (Lambert (2005) \#29; Murakami et al. (2012a, 2012b) \#131; Tanaka and Fordyce $(2014,2015)$ \#132).

(66) Fossa for preorbital lobe of pterygoid sinus in orbit: absent (0); present (1). (Fraser and Purves (1960); Arnold and Heinsohn (1996) \#18; Murakami et al. (2012a, 2012b) \#133; Tanaka and Fordyce (2014, 2015) \#134).

(67) Dorsal development of fossa for preorbital lobe of pterygoid sinus toward the frontal-maxilla suture: absent (0); present (1). (Muizon (1984, 1988); Heyning (1989) \#37 (1997) \#69; Messenger and McGuire (1998) \#1460; Arnold and Heinsohn (1996) \#20; Lambert (2008) \#13; Murakami et al. (2012a, 2012b) \#134; modified from Fajardo-Mellor et al. (2006) \#13; derived from Fraser and Purves (1960) ; Tanaka and Fordyce $(2014,2015)$ \#135).

(68) Postorbital lobe of pterygoid sinus fossa: absent (0); present (1); large and deep (2). (Arnold and Heinsohn (1996) \#18; Geisler and Sanders (2003) \#170; Geisler et al. (2011) \#170 (2012) \#170; Murakami et al. (2012a, 2012b) \#135; derived from Fraser and Purves (1960) ; Tanaka and Fordyce (2014, 2015) \#136).

(69) Anteroposteriorly elongated pterygoid sinus fossa, at level of orbit, bordered by mediolaterally compressed subtemporal crest of frontal: absent (0); present (1). (Murakami et al. (2012a, 2012b) \#136; Tanaka and Fordyce $(2014,2015)$ \#137).

(70) Orbitosphenoid: not contacting lacrimal or lacrimojugal (0); contacting lacrimal or lacrimojugal (1). (Murakami et al. (2012a, 2012b) \#137; Tanaka and Fordyce $(2014,2015)$ \#138).

(71) Ratio of length of hamular process of pterygoid to cranium length: $<0.30(0) ; 0.30-0.44(1) ; 0.45-0.59$ (2); >0.60 (3). The length of the hamular process of the pterygoid is measured from anterior edge of the pterygoid to posterior edge of the hamular process. The cranium length is measured from anterior edge of the antorbital process to posterior edge of occipital condyles. (Murakami et al. (2012a, 2012b) \#138; modified from Heyning (1989) \#18 (1997) \#50; Muizon (1991); Messenger and McGuire (1998) \#1447; Lambert (2005) \#31; Tanaka and Fordyce $(2014,2015)$ \#139).

(72) Keel affecting ventral surfaces of hamular processes: absent (0); present (1). (Muizon (1988); Messenger and McGuire (1998) \#1449; Bianucci (2005) \#14; Murakami et al. (2012a, 2012b) \#139; modified from Fajardo-Mellor et al. (2006) \#10; Tanaka and Fordyce $(2014,2015)$ \#140).

(73) Exposure of medial lamina of pterygoid hamuli in lateral view: complete or broad exposure due to extreme reduction of lateral lamina of pterygoid hamuli (0); no exposure due to a posterior extension of lateral lamina extending posterior to medial lamina (1); medial lamina of pterygoid hamuli exposing lateral lamina through ovoid window in lateral view (2). (Muizon (1988); Fajardo-Mellor et al. (2006) \#11; Murakami et al. (2012a, 2012b) \#140; derived from Noble and Fraser (1971); Tanaka and Fordyce $(2014,2015)$ \#141).

(74) Shape of restricted area between postorbital ridge of frontal and subtemporal crest from ventral view: anteroposteriorly long elliptical (0); wide fan-shape (1); narrow fan-shape (2), rhombus (3). (Tanaka and Fordyce $(2014,2015)$ \#280)

\section{Posterior Basicranium}

(75) Tympanosquamosal recess: very large, forming large fossa bordering entire medial edge of glenoid fossa (0); present and enlarged, forming triangular fossa medial and anteromedial to postglenoid process (1). (Geisler and Sanders (2003) \#178; Geisler et al. (2011) \#178 (2012) \#178; Murakami et al. (2012a, 2012b) \#143; modified from Lambert (2005) \#35; derived from Fraser and Purves (1960), and Fordyce (2002); Tanaka and Fordyce (2014, 2015) \#144).

(76) Fossa for the basisphenoidal sinus: absent (0); present (1). (Fraser and Purves (1960); Mead and Fordyce (2009); Murakami et al. (2012a, 2012b) \#145; Tanaka and Fordyce $(2014,2015)$ \#146).

(77) Posterior portion of periotic fossa of squamosal: fossa absent (0); fossa present but shallow (1); posteromedial portion contains large deep fossa (2). (Geisler and Sanders (2003) \#187; Geisler et al. (2011) \#187 (2012) \#187; Murakami et al. (2012a, 2012b) \#149 and \#151; Tanaka and Fordyce $(2014,2015)$ \#151).

(78) Length of zygomatic process of squamosal as percent of greatest width of maxilla at postorbital process: $>31 \%$ (0); $\leq 30 \%$ (1). (Murakami et al. (2012a, 2012b) \#152; modified from Heyning (1989) \#33, 35, \#65, 67; Geisler and Sanders (2003) \#188; Geisler et al. (2011) \#188 (2012) \#188; Tanaka and Fordyce $(2014,2015)$ \#152)

(79) Fossa for posterior sinus in exoccipital: absent or slightly concave (0); moderately concave (1); forming deep sack-like structure (2). (Murakami et al. (2012a, 2012b) \#161; modified from Muizon (1991); Lambert (2005) \#38; Tanaka and Fordyce (2014, 2015) \#161).

(80) Occipital condyles; on pedicle (0); lacking pedicle, unified with occipital (1). (Tanaka and Fordyce (2014, 2015) \#284)

\section{Periotic}

(81) Relative position of dorsal depth of stapedial muscle fossa and fenestra rotunda: ventral to, or in line with, dorsal edge of fenestra rotunda (0); well dorsal to fenestra rotunda (1). (Geisler and Sanders (2003) \#223; Geisler et al. (2011) \#223 (2012) \#223; Murakami et al. (2012a, 2012b) \#177; Tanaka and Fordyce $(2014,2015)$ \#176). 
(82) Aperture for cochlear aqueduct: smaller than aperture for vestibular aqueduct (0); approximately same size as aperture for vestibular aqueduct (1); much larger than aperture for vestibular aqueduct, with narrow posterior edge (2). (Geisler and Sanders (2003) \#227; Geisler et al. (2011) \#227 (2012) \#227; Murakami et al. (2012a, 2012b) \#181; modified from Muizon (1987); Fordyce (1994); Lambert (2005) \#52; Tanaka and Fordyce $(2014,2015)$ \#180).

(83) Bony connection between posterior process of periotic and squamosal/occipital bones: present (0); absent (ligamentous). (1). (Muizon (1984); Arnold and Heinsohn (1996) \#34; Messenger and McGuire (1998) \#1491; Murakami et al. (2012a, 2012b) \#188; derived from Fraser and Purves (1960); Kasuya (1973); Heyning (1989) ; Tanaka and Fordyce $(2014,2015) \# 187)$.

(84) Posterior process of periotic in lateral view: ventrally bent (0); in same plane as body of periotic (1). (Bianucci (2005) \#19; Murakami et al. (2012a, 2012b) \#189; modified from Arnold and Heinsohn (1996) \#28; Lambert (2005) \#54; Tanaka and Fordyce $(2014,2015)$ \#188).

(85) Angle between posterior process of periotic and long axis of pars cochlearis from dorsal or ventral views: $>135^{\circ}(0)$; $\leq 135^{\circ}$ (1). (Murakami et al. (2012a, 2012b) \#190; modified from Geisler and Sanders (2003) \#246; Lambert (2005) \#54; Geisler et al. (2011) \#246 (2012) \#246; derived from Kasuya (1973); Barnes (1990); Luo and Marsh (1996); Tanaka and Fordyce $(2014,2015)$ \#189).

(86) Length of posterior process of periotic as percent length of pars cochlearis: long, $\geq 85 \%$ (0); short, $\leq 84 \%$ (1). (Murakami et al. (2012a, 2012b) \#193; modified from Barnes (1990); Luo and Marsh (1996) \#24; Geisler and Sanders (2003) \#245; Geisler et al. (2011) \#245 (2012) \#245; Tanaka and Fordyce $(2014,2015)$ \#193).

\section{Tympanic Bulla}

(87) Articulation of posterior process of tympanic bulla with squamosal: process contacting post-tympanic process of squamosal and posterior process of periotic (0); process contacting periotic only (1). (Muizon (1984); Fordyce (1994) \#29; Arnold and Heinsohn (1996) \#34; Messenger and McGuire (1998) \#1481; Lambert (2005) \#56; Murakami et al. (2012a, 2012b) \#197; derived Kasuya (1973) ; Tanaka and Fordyce $(2014,2015)$ \#197).

(88) Width of tympanic bulla as percentage of its length along its long axis: wide, $\geq 65 \%(0)$; narrow and long, $\leq 64 \%$ (1). (Geisler and Sanders (2003) \#251; Bianucci (2005) \#23; Geisler et al. (2011) \#251 (2012) \#251; Murakami et al. (2012a, 2012b) \#198; derived from Kasuya (1973); Tanaka and Fordyce (2014, 2015) \#198).
(89) Lateral furrow of tympanic bulla: shallow groove (0); absent (1); deep, well-defined groove (2). (Murakami et al. (2012a, 2012b) \#200; modified from Muizon (1984, 1988); Arnold and Heinsohn(1996) \#31; Messenger and McGuire (1998) \#1485; Fajardo-Mellor et al. (2006) \#17; Lambert (2008) \#17; derived from Kasuya (1973) ; Tanaka and Fordyce $(2014,2015)$ \#200).

(90) Dorsomedial edge of sigmoid process: expanded anteriorly to oppose lateral tuberosity of periotic (0); not articulating with squamosal or periotic (1) (Murakami et al. (2012a, 2012b) \#202; modified from Geisler and Sanders (2003) \#260; Geisler et al. (2011) \#260 (2012) \#260; modified from Luo and Marsh (1996) \#10; Tanaka and Fordyce (2014, 2015) \#202).

(91) Elliptical foramen of tympanic bulla: present (0); absent or close (1). (Geisler and Sanders (2003) \#261; Geisler et al. (2011) \#261 (2012) \#261; Murakami et al. (2012a, 2012b) \#204; derived from Kasuya (1973); Tanaka and Fordyce $(2014,2015)$ \#204).

(92) Surface of posterior process of tympanic bulla: spiny or irregular edges $(0)$; rounded and pachyostotic (1). (Muizon (1991); Messenger and McGuire (1998) \#1483; Murakami et al. (2012a, 2012b) \#206; derived from Kasuya (1973); Tanaka and Fordyce (2014, 2015) \#206).

(93) Posterior edge of medial prominence of involucrum: approximately in line with posterior edge of lateral prominence (0); distinctly anterior to posterior edge of lateral prominence (1). (Muizon (1987); Geisler and Sanders (2003) \#269; Geisler et al. (2011) \#269 (2012) \#269; Murakami et al. (2012a, 2012b) \#209; derived from Kasuya (1973); Tanaka and Fordyce (2014, 2015) \#209).

(94) Posterior end of ventromedial keel: not protruding and directed medially (0); protruding and directed medially (1). (Geisler and Sanders (2003) \#275; Geisler et al. (2011) \#275 (2012) \#275; Murakami et al. (2012a, 2012b) \#214; Tanaka and Fordyce (2014, 2015) \#213).

\section{Hyals}

(95) Basihyal and thyrohyal shape: arched (0); angled (1). (Murakami et al. (2012a, 2012b) \#216; modified from Bianucci (2005) \#25; Tanaka and Fordyce (2014, 2015) \#215).

\section{Vertebrae}

(96) Dorsal transverse process of atlas: developed dorsolaterally (0); absent or rudimentary obtuse angle (1). (Murakami et al. (2012a, 2012b) \#217; modified from Muizon (1988); Barnes (1990); Tanaka and Fordyce (2014, 2015) \#216).

(97) Roof of neural canal of atlas: arched (0); straight (1). (Murakami et al. (2012a, 2012b) \#218; Tanaka and Fordyce (2014, 2015) \#217). 
(98) Postzygapophysis of axis in anterior view: appearing as crest, elongated dorsolaterally (0); appearing as rudimentary crest (1); not appearing (2). (Murakami et al. (2012a, 2012b) \#219; Tanaka and Fordyce $(2014,2015)$ \#218).

(99) Cervical vertebrae: unfused (0); atlas and axis fused (1); C1-C3 or C1-C4 fused (2); C1-C6 or C1-C7 fused (3); C2-C7 fused (4). (Murakami et al. (2012a, 2012b) \#220; modified from Arnold and Heinsohn (1996) \#9; Messenger and McGuire (1998) \#1501; Geisler and Sanders (2003) \#278, 279; Fajardo-Mellor et al. (2006) \#18; Lambert (2008) \#18; Geisler et al. (2011) \#278, 279 (2012) \#278, 279; derived from Allen (1923); Miller (1923); Fraser and Noble (1971); De Smet (1977); Rommel (1990) ; Tanaka and Fordyce $(2014,2015)$ \#219).

(100) Length of cervicals (C1-C7) as percent of height of vertebral body plus neural canal of atlas: long, $>150 \%$ (0); short, <150\% (1). (Murakami et al. (2012a, 2012b) \#221; Tanaka and Fordyce (2014, 2015) \#220).

(101) Transverse processes of lumbar vertebrae: extend parallel to anterior and posterior borders (0); triangular (1). (Muizon (1984, 1985, 1988); Messenger and McGuire (1998) \#1502; Geisler and Sanders (2003) \#285; Geisler et al. (2011) \#285 (2012) \#285; Murakami et al. (2012a, 2012b) \#224; Tanaka and Fordyce $(2014,2015)$ \#223).

\section{Scapula}

(102) Anterodorsal part of scapula: rounded (0); almost rectilinear (1). (Murakami et al. (2012a, 2012b) \#232; Tanaka and Fordyce $(2014,2015)$ \#232).

(103) Ventral projection on anterior border of scapula: absent (0); present (1). (Fajardo-Mellor et al. (2006) \#26; Murakami et al. (2012a, 2012b) \#233; derived from Noble and Fraser (1971); Tanaka and Fordyce (2014, 2015) \#233).

(104) Coracoid process of scapula: not expanded distally (0); expanded distally (1); notably reduced or absent (2). (Murakami et al. (2012a, 2012b) \#237; modified from Muizon (1987, 1994); Messenger and McGuire (1998) \#1504; Geisler and Sanders (2003) \#292; Lambert (2005) \#73; Bianucci (2005) \#33; Geisler et al. (2011) \#292; derived from True (1904); Tanaka and Fordyce $(2014,2015)$ \#237).

(105) Coracoid process of scapula, with glenoid fossa: directed horizontally (0); directed anteroventrally (1). (modified from Murakami et al. (2012a, 2012b) \#238; modified Barnes (1990); Tanaka and Fordyce (2014, 2015) \#238).

(106) Acromion of scapula: narrow and not expanded distally (0); expanded distally (1). (Murakami et al. (2012a, 2012b) \#239; modified from Bianucci (2005) \#34; Tanaka and Fordyce $(2014,2015)$ \#239).

(107) Acromion of scapula, when glenoid fossa direct ventrally: directed horizontally $(0)$; directed antero- dorsally (1); directed anteroventrally (2). (Murakami et al. (2012a, 2012b) \#240; modified from Barnes (1990); Tanaka and Fordyce $(2014,2015)$ \#240).

\section{Forelimb (except scapula)}

(108) Ratio of length of humerus to length of radius: long, $>1.1$ (0); short, <0.8 (1). (Murakami et al. (2012a, 2012b) \#242; modified from Sanders and Barnes (2002); Geisler and Sanders (2003) \#297; Geisler et al. (2012; 2011) \#297; Tanaka and Fordyce (2014, 2015) \#242).

(109) Prominent deltoid crest on anterior edge of humerus: present, forms greatest anteroposterior diameter along shaft (0); forming a knob-like tuberosity (1); tuberosity or crest absent (2). (Geisler and Sanders (2003) \#294; Geisler et al. (2011) \#294 (2012) \#294; Murakami et al. (2012a, 2012b) \#244; derived from Sanders and Barnes (2002); Tanaka and Fordyce $(2014,2015)$ \#244).

(110) Radial and ulnar facets of humerus in lateral view: facets forming a semicircular articulation surface (0); facets forming an obtuse angle (1). (Barnes, Barnes (1990); Geisler and Sanders (2003) \#296; Geisler et al. (2011) \#296 (2012) \#296; Murakami et al. (2012a, 2012b) \#245; Tanaka and Fordyce (2014, 2015) \#245).

(111) Olecranon process: present as a distinct process (0); present as a slightly raised proximal posterior edge (1); absent (2). (Messenger and McGuire (1998) \#1507; Geisler and Sanders (2003) \#296; Geisler et al. (2011) \#284 (2012) \#284; Murakami et al. (2012a, 2012b) \#246; modified from Muizon (1984); Barnes (1990); Arnold and Heinsohn (1996) \#10; Fajardo-Mellor et al. (2006) \#28; derived from Howell (1927); Bianucci (2005) \#37; Tanaka and Fordyce $(2014,2015)$ \#246).

\section{Added characters to Tanaka and Fordyce (2015)}

(112) Mandible fossa of squamosal: wider than squamosal reces (0); narrower than squamosal recess (1).

(113) Anterior end of zygomatic process in ventral view: rounded (0); tapered (1).

(114) Most anterior maxillary foramen: anterior to or in line with antorbital notch (0); posterior to antorbital notch (1). (Ichishima and Kimura (2005); Colpaert et al. (2015) \#3)

(115) Longitudinal sulcus through premaxillary eminence: 0 , absent; 1 , present. This additional sulcus is thought to be present in Brabocetus, at least on right side. (de Muizon (1984); Colpaert et al. (2015) \#6)

(116) Dorsal extension of pterygoid sinus fossa between frontal and maxilla: absent or poorly developed (0); deep (1). (Lambert (2008); Fajardo-Mellor et al. (2006); Colpaert et al. (2015) \#13)

(117) Number of teeth in each upper tooth row: tooth counts $>35$ (0); tooth counts between 35 and 30 
(1); minimum tooth counts 18-24 and maximum tooth counts 26-29 (2); minimum tooth counts 8-17 and maximum tooth counts 20-25 (3). (FajardoMellor et al. (2006); Lambert (2008); Colpaert et al. (2015) \#15)

(118) Spinous process of axis: short, extends posteriorly only to about C4 (0); long, nearly contacts spinous process of C7 (1). (Fajardo-Mellor et al. (2006); Colpaert et al. (2015) \#19)

(119) Transverse foramina (vertebrarterial canal) of C4: complete (0); incomplete or absent (1). (FajardoMellor et al. (2006); Colpaert et al. (2015) \#20)

(120) Transverse process of axis: well developed (0); weakly developed or absent (1). (Fajardo-Mellor et al. (2006); Lambert (2008); Colpaert et al. (2015) \#21)

(121) Metapophyses of spinous processes: well developed (0); absent or weakly developed (1). (FajardoMellor et al. (2006); Colpaert et al. (2015) \#22)

(122) Acromion and coracoid processes of scapula: acromion longer than coracoid (0); acromion shorter than coracoid (1). (Fajardo-Mellor et al. (2006); Colpaert et al. (2015) \#23)

(123) Supraspinous fossa: broad (0); narrow (1). (Fajardo-Mellor et al. (2006); Colpaert et al. (2015) \#24)

\section{REFERENCES}

Aguirre-Fernández, G., Barnes, L.G., Aranda-Manteca, F.J., and Fernández-Rivera, J.R. 2009. Protoglobicephala mexicana, a new genus and species of Pliocene fossil dolphin (Cetacea; Odontoceti; Delphinidae) from the Gulf of California, Mexico. Boletin de la Sociedad Geologica Mexicana, 61(2):245-265.

Allen, G.M. 1923. The black finless porpoise, Meomeris. Bulletin of the Museum of Comparative Zoology, 65(7):233-256.

Arnold, P.W., and Heinsohn, G.E. 1996. Phylogenetic status of the Irrawaddy dolphin Orcaella brevirostris (Owen in Gray): a cladistic analysis. Memoirs of the Queensland Museum, 39(2):141-204.

Barnes, L.G. 1984a. Fossil odontocetes (Mammalia: Cetacea) from the Almejas Formation, Isla Cedros, Mexico. Paleobios, 42:1-46.

Barnes, L.G. 1984b. Whales, dolphins and porpoises; origin and evolution of the Cetacea. In Gingerich, P.D., and Badgle, C.E. (eds.), Mammals. Notes for a short course, University of Atennessee, Department of Geological Science.

Barnes, L.G. 1985a. Evolution, taxonomy and antitropical distributions of the porpoises (Phocoenidae, Mammalia). Marine Mammal Science, 1(2):149-165.

Barnes, L.G. 1985b. Fossil pontoporiid dolphins (Mammalia: Cetacea) from the Pacific coast of North
America. Contributions to Science, Natural History Museum of Los Angeles County, 363:1-34.

Barnes, L.G. 1990. The fossil record and evolutionary relationships of the genus Tursiops, p. 3-26. In Leatherwood, S., and Reeves, R.R. (eds.), The bottlenose dolphin. Academic Press Inc, San Diego, New York.

Bianucci, G. 2005. Arimidelphis sorbinii a new small killer whale-like dolphin from the Pliocene of Marecchia River (Central eastern Italy) and a phylogenetic analysis of the Orcininae (Cetacea: Odontoceti). Rivista Italiana di Paleontologia e Stratigrafia, 111(2):329344.

Colpaert, W., Bosselaers, M., and Lambert, O. 2015. Out of the Pacific: a second fossil porpoise from the Pliocene of the North Sea Basin. Acta Paleontologica Polonica, 60(1):1-10.

Curry, B.E. 1992. Facial anatomy and potential function of facial structures for sound production in the harbor porpoise (Phocoena phocoena) and Dall's porpoise (Phocoenoides dalli). Canadian Journal of Zoology, 70(11):2103-2114.

de Muizon, C. 1984. Les vertébrés fossiles de la Formation Pisco (Pérou). deuxiéme partie: les Odontocétes (Cetacea, Mammalia) du Pliocéne inférieur de SudSacaco. Travaux de l'Institut Français d'Études Andines, 27:1-188.

de Muizon, C. 1985. Nouvelles données sur le diphylétisme des Dauphins de rivière (Odontoceti, Cetacea, Mammalia). Comptes rendus l'Academie des Sciences series 2,, 301:359-362.

de Muizon, C. 1987. The affinities of Notocetus vanbenedeni, an Early Miocene platanistoid (Cetacea, Mammalia) from Patagonia, southern Argentina. American Museum novitates, 2904:1-27.

de Muizon, C. 1988. Les relations phylogenetiques des Delphinida (Cetacea, mammalia). Annales de paléontologie, 74(4):159-227.

de Muizon, C. 1991. A new Ziphiidae (Cetacea) from the Early Miocene of Washington State (USA) and phylogenetic analysis of the major groups of odontocetes. Bulletin du Muséum National d'Histoire Naturelle, 12(3-4):279-326.

de Muizon, C. 1994. Are the squalodonts related to the platanistoids? Proceedings of the San Diego Society of Natural History, 29:135-146.

De Smet, W.M.A. 1977. The regions of the cetacean vertebral column volume 3, p. 59-80. In Harrison, R.J. (ed.), Functional anatomy of marine mammals. Academic Press, London.

Fajardo-Mellor, L., Berta, A., Brownell, R.L., Boy, C.C., and Goodall, N.P. 2006. The phylogenetic relationships and biogeography of true porpoises (Mammalia: Phocoenidae) based on morphological data. Marine Mammal Science, 22(4):910-932.

Flower, W.H. 1867. Description of the skeleton of Inia geoffrensis and the skull of Pontoporia blainvillii, with remarks on the systematic position of these animals in the Order Cetacea. Transactions of the Zoological Society of London, 6(3):87-116. 
Flower, W.H. 1884. On the characters and divisions of the Family Delphinidae. Proceedings of the Zoological Society of London, 1883:466-513.

Fordyce, R.E. 1994. Waipatia maerewhenua, new genus and new species (Waipatiidae, new family), an archaic Late Oligocene dolphin (Cetacea: Odontoceti: Platanistoidea) from New Zealand. Proceedings of the San Diego Society of Natural History, 29:147176.

Fordyce, R.E. 2002. Simocetus rayi (Odontoceti: Simocetidae, new family): A bizarre new archaic Oligocene dolphin from the eastern North Pacific. Smithsonian Contributions to Paleobiology, 93:185222.

Fraser, F.C., and Purves, P.E. 1960. Hearing in cetaceans: evolution of the accessory air sacs and the structure of the outer and middle ear in recent cetaceans. Bulletin of the British Museum of Natural History (Zoology) 7:1-140.

Geisler, J.H., Godfrey, S.J., and Lambert, O. 2012. A new genus and species of late Miocene inioid (Cetacea, Odontoceti) from the Meherrin River, North Carolina, USA. Journal of Vertebrate Paleontology, 32(1):198-211.

Geisler, J.H., McGowen, M.R., Yang, G., and Gatesy, J. 2011. A supermatrix analysis of genomic, morphological, and paleontological data from crown Cetacea. BMC Evolutionary Biology, 11:1-33.

Geisler, J.H., and Sanders, A.E. 2003. Morphological evidence for the phylogeny of Cetacea. Journal of Mammalian Evolution, 10(1/2):23-129.

Heyning, J.E. 1989. Comparative facial anatomy of beaked whales (Ziphiidae) and a systematic revision among the families of extant Odontoceti. Contributions in Science, Natural History Museum of Los Angeles County., 405:1-64.

Heyning, J.E. 1997. Sperm whale phylogeny revisited: analysis of the morphological evidence. Marine Mammal Science, 13(4):596-613.

Howell, A.B. 1927. Contribution to the anatomy of the Chinese finless porpoise Neomeris phocaenoides. Proceedings of The United States National Museum, 70(13):1-43.

Ichishima, H., and Kimura, M. 2005. Haborophocoena toyoshimai, a new Early Pliocene porpoise (Cetacea; Phocoenidae) from Hokkaido, Japan. Journal of Vertebrate Paleontology, 25(3):655-664.

Kasuya, T. 1973. Systematic consideration of recent toothed whales based on the morphology of tympano-periotic bone. Scientific Reports of the Whales Research Institute, Tokyo, 25:1-103.

Kellogg, R. 1936. A review of the Archaeoceti. Carnegie Institution of Washington publication, 482:1-366.

Lambert, O. 2005. Phylogenetic affinities of the longsnouted dolphin Eurhinodelphis (Cetacea, Odontoceti) from the Miocene of Antwerp, Belgium. Palaeontology, 48(3):653-679.
Lambert, O. 2008. A new porpoise (Cetacea, Odontoceti, Phocoenidae) from the Pliocene of the North Sea. Journal of Vertebrate Paleontology, 28(3):863-872.

Luo, Z., and Marsh, K. 1996. Petrosal (periotic) and inner ear of a Pliocene kogiine whale (Kogiinae, Odontoceti): implications on relationships and hearing evolution of toothed whales. Journal of Vertebrate Paleontology, 16(2):328-348.

Marsh, H., Lloze, R., Heinsohn, G.E., and Kasuya, T. 1989. Irrawaddy dolphin - Orcaella brevirostris (Gray, 1866), p. 101-118. In Ridgway, S.H., and Harrison, S. (eds.), Handbook of marine mammals. Volume 4: river dolphins and the larger toothed whales.

Mead, J.G., and Fordyce, R.E. 2009. The therian skull: a lexicon with emphasis on the odontocetes. Smithsonian Contributions to Zoology, 627:1-248.

Messenger, S.L., and McGuire, J.A. 1998. Morphology, molecules, and the phylogenetics of cetaceans. Systematic Biology, 47(1):90-124.

Miller, G.S. 1923. The telescoping of the cetacean skull. Smithsonian Miscellaneous Collections, 76(5):1-70.

Moore, J.C. 1968. Relationships among the living genera of beaked whales with classifications, diagnoses and keys. Fieldiana: Zoology, 53(4):509-598.

Murakami, M., Shimada, C., Hikida, Y., and Hirano, H. 2012a. A new basal porpoise, Pterophocaena nishinoi (Cetacea, Odontoceti, Delphinoidea), from the upper Miocene of Japan and its phylogenetic relationships. Journal of Vertebrate Paleontology, 32(5):1157-1171.

Murakami, M., Shimada, C., Hikida, Y., and Hirano, H. 2012b. Two new extinct basal phocoenids (Cetacea, Odontoceti, Delphinoidea), from the upper Miocene Koetoi Formation of Japan and their phylogenetic significance. Journal of Vertebrate Paleontology, 32(5):1172-1185.

Murakami, M., Shimada, C., Hikida, Y., Soeda, Y., and Hirano, H. 2014. Eodelphis kabatensis, a new name for the oldest true dolphin Stenella kabatensis Horikawa, 1977 (Cetacea, Odontoceti, Delphinidae), from the upper Miocene of Japan, and the phylogeny and paleobiogeography of Delphinoidea. Journal of Vertebrate Paleontology, 34(3):491-511.

Noble, B., and Fraser, F. 1971. Description of a skeleton and supplementary notes on the skull of a rare porpoise Phocoena sinus Norris \& McFarland 1958. Journal of Natural History, 5(4):447-464.

Rommel, S. 1990. Osteology of the bottlenose dolphin, p. 29-49. In Leatherwood, S., and Reeves, R.R. (eds.), The bottlenose dolphin. Academic Press Inc, San Diego, New York.

Sanders, A.E., and Barnes, L.G. 2002. Paleontology of the late Oligocene Ashley and Chandler Bridge formations of South Carolina, 2: Micromysticetus rothauseni, a primitive cetotheriid mysticete (Mammalia: Cetacea). Smithsonian Contributions to Paleobiol$\operatorname{ogy}(93): 271-293$.

Tanaka, Y., and Fordyce, R.E. 2014. Fossil dolphin Otekaikea marplesi (latest Oligocene, New Zealand) expands the morphological and taxonomic diversity 
Tanaka, Y., and Fordyce, R.E. 2015. A new Oligo-Miocene dolphin from New Zealand: Otekaikea huata expands diversity of the early Platanistoidea. Palaeontologia Electronica, 18(2.23A):1-71.

True, F.W. 1904. The whalebone whales of the western North Atlantic compared with those occurring in
European waters with some observations on the species of the North Pacific. Smithson Contribution to Knowledge, 33:1-332.

Whitmore, F.C., and Sanders, A.E. 1977. Review of the Oligocene Cetacea. Systematic Zoology, 25(4):304320. 


\section{APPENDIX 4.}

List of modifications to the original codings and character descriptioons of Tanaka and Fordyce (2015). The changed codings were originally coded by Murakami (2012b). The initial number refers to the character number in Appendix 3. Character numbers are identified in parentheses.

(26) Maxilla on dorsal surface of skull: does not contact supraoccipital posteriorly, maxilla separated by frontal and/or parietal (0); contact present (1). Haborophocoena toyoshimai ? to 0

(46) Temporal fossa shape in lateral view: height lower than anteroposterior length (0); higher (1); lower and its posterior end is rounded (2).
Haborophocoena minutus ? to 0 Haborophocoena toyoshiimai 0 to 1

(56) Postglenoid process in lateral view: tapering ventrally (0); squared off ventrally (1); same as state 1 except very wide anteroposterior diameter of process (2).

Haborophocoena toyoshimai 0 to 1

(84) Posterior process of periotic in lateral view: ventrally bent (0); in same plane as body of periotic (1). Haborodelphis toyoshimai 0 to 1

Miophocaena nishinoi ? to 0 Semirostrum ceruttii 1 to 0 
TANAKA \& ICHISHIMA: A NEW SKULL OF NUMATAPHOCOENA

\section{APPENDIX 5}

Treefile of the analysis of Tanaka and Ichishima (2016).

Available in zipped format with Appendix 1and Appendix 2online at palaeo-electronica.org/content/2016/1663-a-new-skull-of-numataphocoena 